Nevada

Environmental

Restoration

Project

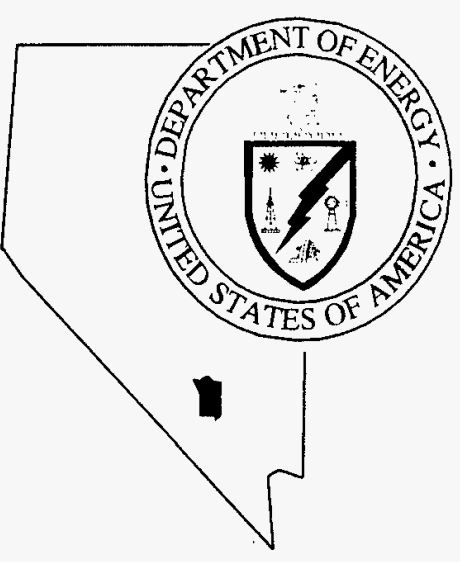

Corrective Action Investigation Plan for the Roller Coaster RADSAFE Area, Corrective Action Unit 407,

Tonopah Test Range, Nevada receivfo MAY 18998

OSTI

Controlled Copy No.:

Revision No.: 0

April 1998

Approved for public release; further distribution is authorized.

Environmental Restoration 
This report has been reproduced directly from the best available copy.

Available to DOE and DOE contractors from the Office of Scientific and Technical Information, P.O. Box 62, Oak Ridge, TN 37831; prices available from (423) 576-8401.

Available to the public from the National Technical Information Service, U.S. Department of Commerce, 5285 Port Royal Road, Springfield, VA 22161, telephone (703) 487-4650. 


\section{CORRECTIVE ACTION INVESTIGATION PLAN FOR THE ROLLER COASTER RADSAFE AREA, CORRECTIVE ACTION UNIT 407, TONOPAH TEST RANGE, NEVADA}

DOE Nevada Operations Office

Las Vegas, Nevada

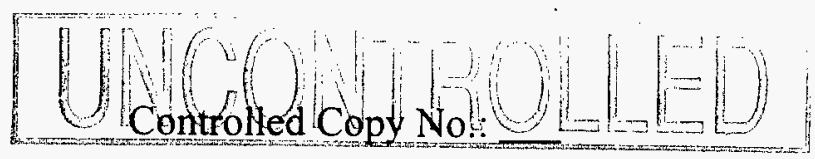

Revision No.: 0

April 1998

Approved for public release; further distribution is authorized. 


\section{DISCLAIMER}

This report was prepared as an account of work sponsored by an agency of the United States Government. Neither the United States Government nor any agency thereof, nor any of their employees, makes any warranty, express or implied, or assumes any legal liability or responsibility for the accuracy, completeness, or usefulness of any information, apparatus, product, or process disclosed, or represents that its use would not infringe privately owned rights. Reference herein to any spe. cific commercial product, process, or service by trade name, trademark, manufacturer, or otherwise does not necessarily constitute or imply its endorsement, recommendation, or favoring by the United States Government or any agency thereof. The views and opinions of authors expressed herein do not necessarily state or reflect those of the United States Government or any agency thereof. 


\section{CORRECTIVE ACTION INVESTIGATION PLAN FOR THE ROLLER COASTER RADSAFE AREA, CORRECTIVE ACTION UNIT 407, TONOPAH TEST RANGE, NEVADA}
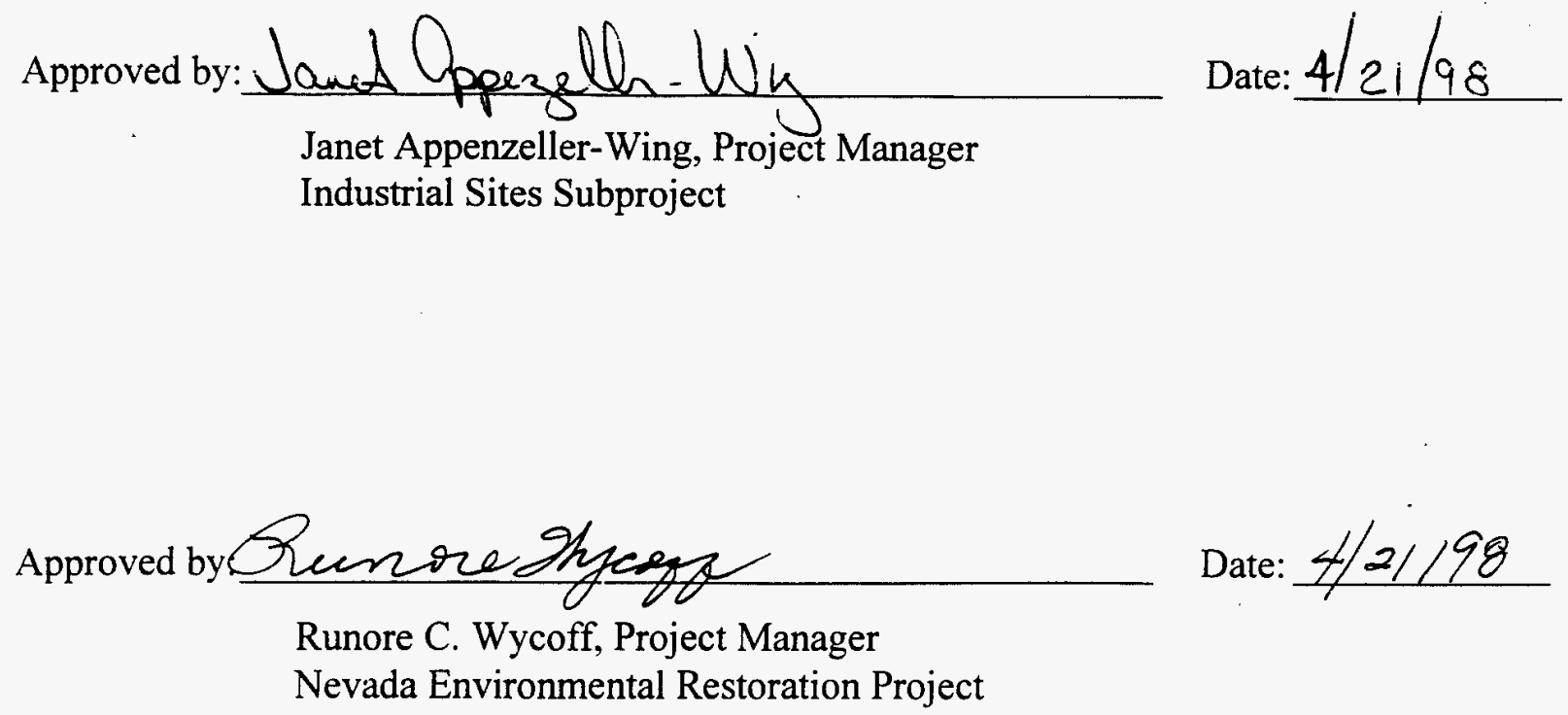


\section{Table of Contents}

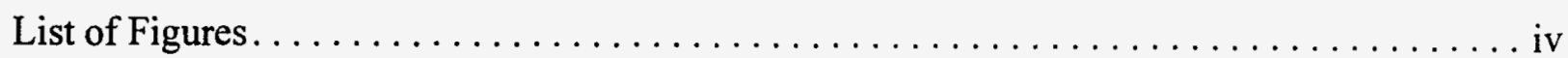

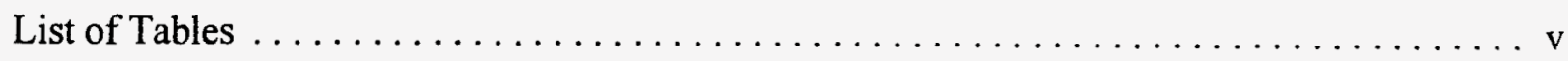

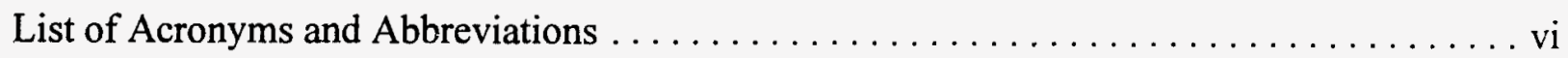

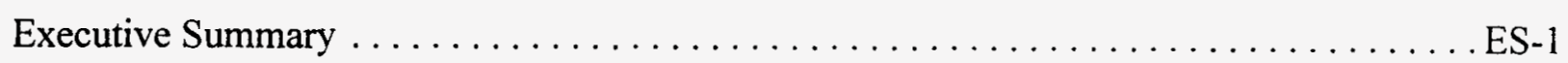

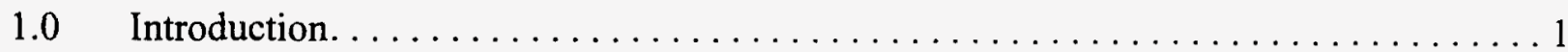

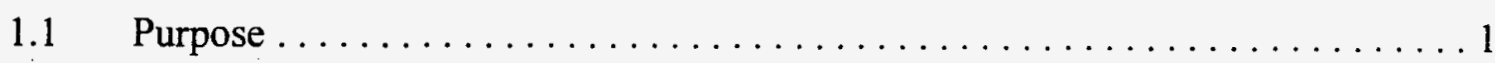

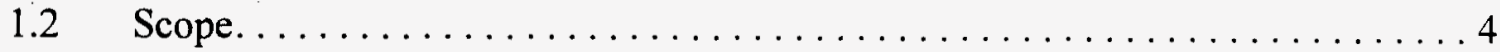

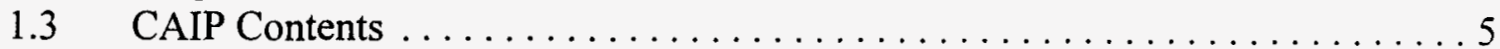

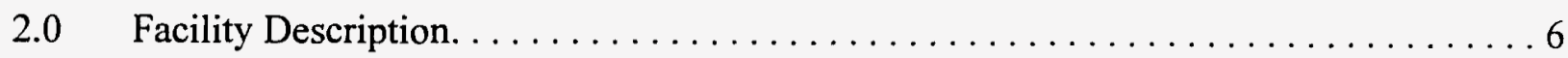

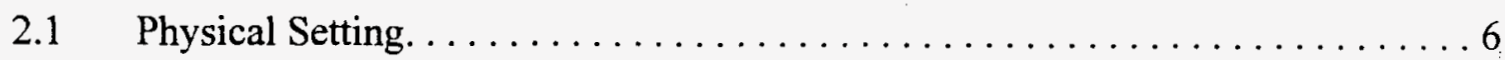

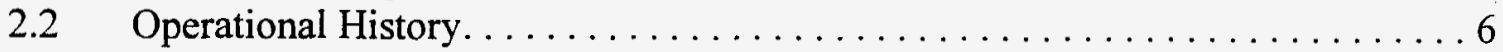

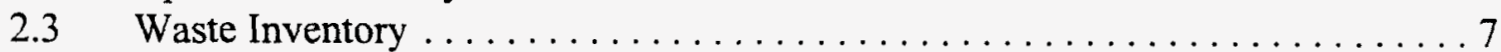

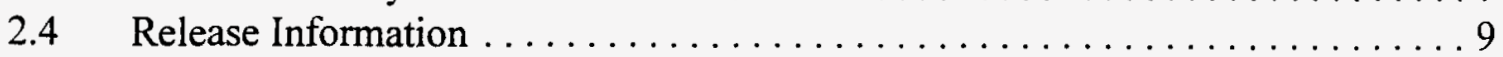

$2.5 \quad$ Investigative Background $\ldots \ldots \ldots \ldots \ldots \ldots \ldots \ldots \ldots \ldots \ldots$

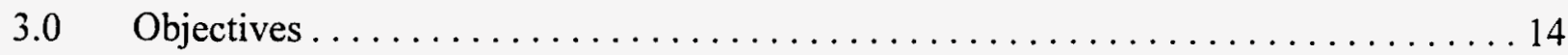

$3.1 \quad$ Conceptual Site Model .................................. 14

3.2 Contaminants of Potential Concern . . . . . . . . . . . . . . . . . . . . 14

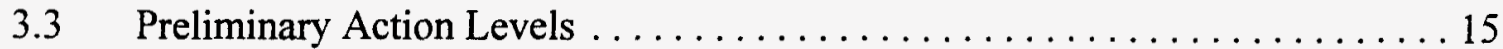

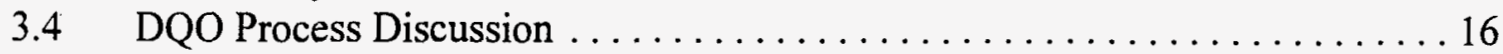

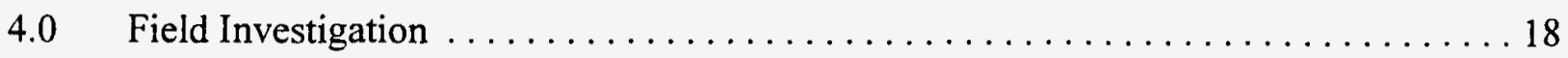

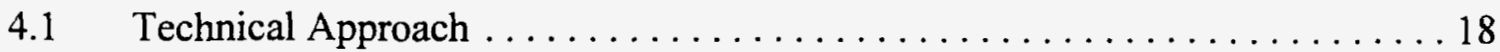

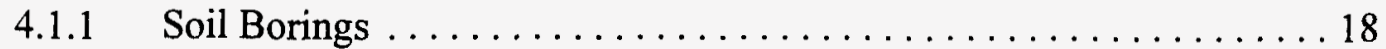

$4.1 .2 \quad$ Field Screening. . . . . . . . . . . . . . . . . . . . . 20

4.1.3 Environmental Samples ............................. 21

4.1.4 Quality Control Samples......................... 22

4.1.5 Background Samples ............................. 22

4.1.6 Geotechnical Samples........................ 23

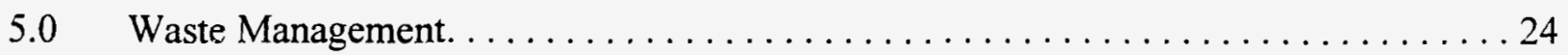

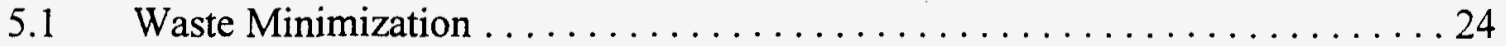

5.2 Potential Waste Streams . . . . . . . . . . . . . . . . . . . . . 25

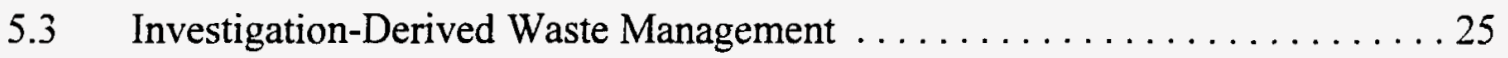

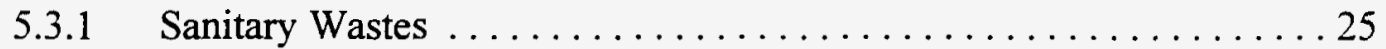

5.3 .2 Low-Level Waste . . . . . . . . . . . . . . . . . . . 26

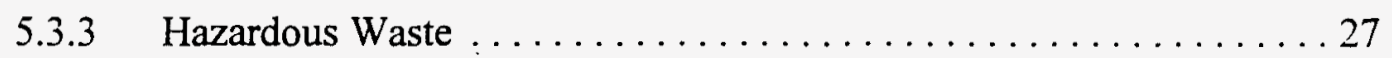

5.3 .4 Mixed Wastes ................................ 28 


\section{Table of Contents (Continued)}

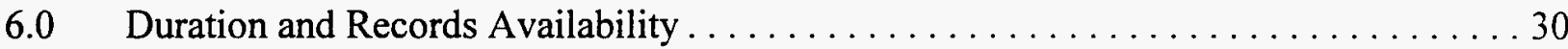

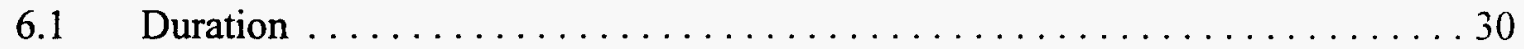

6.2 Records Availability . . . . . . . . . . . . . . . . . . . . . . . . 30

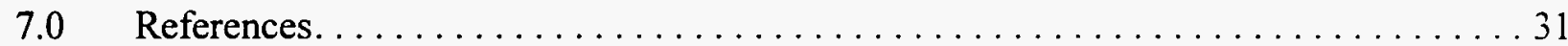

\section{Appendix A - Data Quality Objectives}

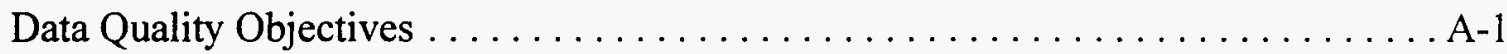

Identify the members of the Scoping Team:................. A-1

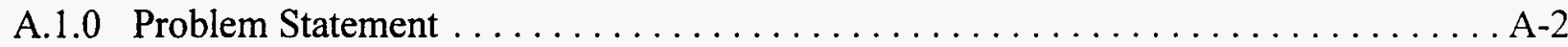

A.1.1 State the Problem $\ldots \ldots \ldots \ldots \ldots \ldots \ldots \ldots \ldots \ldots \ldots \ldots \ldots \ldots \ldots \ldots \ldots \ldots \ldots \ldots \ldots \ldots, 2$

A.1.1.1 Problem to be resolved ....................... A-2

A.1.1.2 Describe the site history and known or suspected sources of contamination...........................

A.2.0 Develop/Refine the Conceptual Model. ....................... A-4

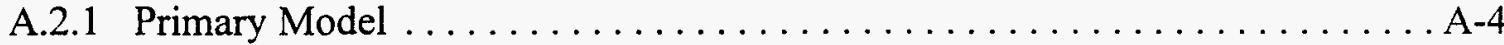

A.2.2 Alternate Model $\ldots \ldots \ldots \ldots \ldots \ldots \ldots \ldots \ldots \ldots \ldots \ldots \ldots \ldots \ldots \ldots \ldots$

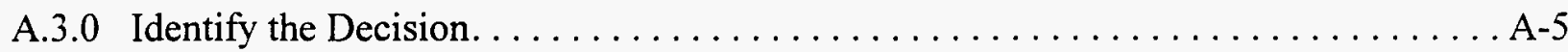

A.4.0 Identify the Inputs to the Decision $\ldots \ldots \ldots \ldots \ldots \ldots \ldots \ldots \ldots \ldots \ldots \ldots \ldots \ldots \ldots \ldots \ldots$

A.4.1 Identify the information inputs needed to resolve the decision and prepare a list of all the data needed to solve the decision . . . . . . . . . . . . 6

A.4.2 List types of potential contaminants and affected media . . . . . . . . . A-6

A.4.3 Identify potential sampling approaches and appropriate analytical methods

A.5.0 Define the Boundaries of the Study $\ldots \ldots \ldots \ldots \ldots \ldots \ldots \ldots \ldots \ldots \ldots \ldots \ldots \ldots \ldots \ldots$

A.5.1 Define the geographic areas of the field investigation $\ldots \ldots \ldots \ldots \ldots \ldots$ A 8

A.5.2 Define the temporal boundaries of the decision . . . . . . . . . . . . A 8

A.5.2.1 Determine when to collect data .................. A

A.5.3 Identify any practical constraints on data collection $\ldots \ldots \ldots \ldots \ldots \ldots$ A-8

A.6.0 Develop a Decision Rule - Define a Logical Basis for Choosing Among Alternative Actions . . . . . . . . . . . . . . . . . . . . . . 10

A.6.1 Specify the action level or preliminary action level for the decision ....... A-10

A.6.2 Specify the variables acting on the corrective action decisions . . . . . . . A A-10 


\section{Table of Contents (Continued)}

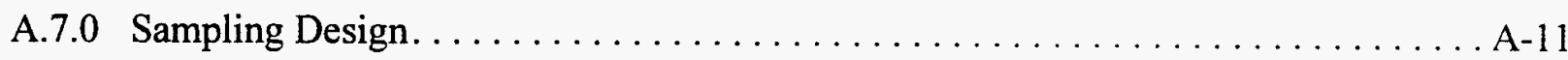

A.7.1 Develop general sampling and analysis design $\ldots \ldots \ldots \ldots \ldots \ldots \ldots$ A-11

A.7.2 Select the most resource-effective sampling design that satisfies all of the DQOs.

A.7.3 Document the operational details and theoretical assumptions of the selected design in the sampling and analysis plan

Appendix B - Project Organization

B.1.0 Project Organization .

Appendix C - NDEP Document Review Sheets 


\section{List of Figures}

Number

1-1 Tonopah Test Range Location Map

2

1-2 Location of CAU 407, Roller Coaster RADSAFE Area, Tonopah Test Range... . . 3

2-1 Site Location Map, Roller Coaster RADSAFE Area, Tonopah Test Range, Nye County, Nevada............................... 8

2-2 Roller Coaster RADSAFE Area 1993 Geophysical Survey Location Map, Tonopah Test Range............................... 10

2-3 Roller Coaster RADSAFE Area 1998 Geophysical Survey Location Map, Tonopah Test Range................................. 11

2-4 Roller Coaster RADSAFE Area EM-61 Survey................. 13

4-1 Proposed Soil Boring Locations, Roller Coaster RADSAFE Area, Tonopah Test Range, Nye County, Nevada 
3-1 Laboratory Analytical Requirements $\ldots \ldots \ldots \ldots \ldots \ldots \ldots \ldots \ldots \ldots \ldots \ldots \ldots$

4-1 Geotechnical Analyses . . . . . . . . . . . . . . . . . . . 23 


\section{List of Acronyms and Abbreviations}

bgs Below ground surface

CADD Corrective Action Decision Document

CAIP Corrective Action Investigation Plan

CAS Corrective Action Site

CAU Corrective Action Unit

CFR Code of Federal Regulations

COPC Contaminant(s) of Potential Concern

DOE U.S. Department of Energy

DOE/NV U.S. Department of Energy, Nevada Operations Office

DOT U.S. Department of Transportation

DQO Data quality objective(s)

DU Depleted uranium

EM Electromagnetic

EPA U.S. Environmental Protection Agency

FFACO Federal Facility Agreement and Consent Order

FIDLER Field instrument for the detection of low energy radiation

ft Foot (feet)

GPR Ground-penetrating radar

HASP Health and Safety Plan

IDW Investigation-derived waste

IT IT Corporation

km. Kilometer(s)

LLW Low-level waste

$\mathrm{m}$

Meter(s) 


\section{List of Acronyms and Abbreviations (Continued)}

$\begin{array}{ll}\text { MEK } & \text { Methyl ethyl ketone } \\ \mathrm{mHz} & \text { Megahertz } \\ \mathrm{mi} & \text { Mile(s) } \\ \mathrm{mg} / \mathrm{kg} & \text { Milligram(s) per kilogram } \\ \mathrm{mg} / \mathrm{L} & \text { Milligram(s) per liter }\end{array}$

MS/MSD Matrix spike/matrix spike duplicate

NAC Nevada Administrative Code

NDEP Nevada Department of Environmental Protection

NTS Nevada Test Site

NTSWAC Nevada Test Site Waste Acceptance Criteria

OREP Off-Site Radiation Exposure Review Project

PCB Polychlorinated biphenyl(s)

$\mathrm{pCi} / \mathrm{g} \quad$ Picocurie(s) per gram

$\mathrm{pCi} / \mathrm{L} \quad$ Picocurie(s) per liter

POC Performance Objective Criteria

PPE Personal protective equipment

ppm Part(s) per million

PRG Preliminary Remediation Goal(s)

QA/QC Quality assurance/quality control

QAPP Quality Assurance Project Plan

QC Quality control

RADSAFE Radiological Survey

RCRA Resource Conservation and Recovery Act

RCRSA Roller Coaster RADSAFE Area 


\section{List of Acronyms and Abbreviations (Continued)}

REECo Reynolds Electrical \& Engineering Co.. Inc.

SAIC Science Applications International Corporation

SVOC Semivolatile organic compound(s)

TCLP Toxicity Characteristic Leaching Procedure

TID Tamper-indicating device(s)

TPH Total petroleum hydrocarbon

TRU Transuranic

TTR Tonopah Test Range

VOC Volatile organic compound(s)

$\mu \mathrm{g} / \mathrm{L} \quad$ Microgram(s) per liter 


\section{Executive Summary}

The Corrective Action Investigation Plan for Corrective Action Unit 407, the Roller Coaster RADSAFE Area, has been developed in accordance with the Federal Facility Agreement and Consent Order that was agreed to by the U.S. Department of Energy, Nevada Operations Office; the State of Nevada Division of Environmental Protection; and the U.S. Department of Defense. Corrective Action Unit 407 consists of a single Corrective Action Site. TA-23-001-TARC.

The Roller Coaster RADSAFE Area was used during May and June, 1963, to decontaminate vehicles, equipment, personnel, and possibly animals from the Clean Slate weapons tests. Liquid wastes from the decontamination (decon) operations were drained from gravel pads to two decon sumps, and contaminated debris and solid waste were disposed of in a pit. The vehicle decon area, the decon sumps, and the waste pit have been backfilled and are currently contained within a fenced area at the site. The gravel from the personnel decon line, or hotline, was removed and disposed of in the pit at the end of the project; the site was backfilled.

Based on site history collected to support the Data Quality Objectives process, contaminants of potential concern (COPCs) for the site include plutonium, depleted uranium, methyl ethyl ketone, lead, sulfuric acid, semivolatile organic compounds, and petroleum hydrocarbons. A conceptual site model for the Corrective Action Unit was developed as follows:

- COPCs primarily associated with the decon fluids were released into the soil at the hotline, vehicle decon area, and the two decon sumps (Figure 2-1).

- COPCs are limited vertically to less than 9-meters (m) (30-feet [ $\mathrm{ft}]$ ) and horizontally to 3-m (10-ft) from the bottom and sides of the two decon sumps and the vehicle decon area.

- COPCs in the form of solids were disposed of in the waste disposal pit.

- Semivolatile organic compounds and hydrocarbons originating from vehicle decon activities are at low concentrations.

A more detailed conceptual model is presented in Section 3.0 of the investigation plan. The conceptual model serves as the basis for the sampling strategy. 
The technical approach for investigating this Corrective Action Unit consists of the following activities:

- Geophysical surveys inside the fenced area to identify buried metallic debris

- Ground-Penetrating Radar surveys to locate the vehicle decon area, sumps, and waste disposal pit

- Surface and subsurface biased sampling at the hotline area, vehicle decon area, the western-most sump, the disposal pit, and the drainage swale

- Surface and subsurface sampling for background

Field-screening methods will be used to detect preliminary concentrations of volatile organics and radioactivity. Samples will be collected for laboratory analysis and verification at each boring. Additional sampling and analytical details are presented in Section 4.0 of the Corrective Action Investigation Plan. Details of the waste management strategy for the Corrective Action Unit are included in Section 5.0 of the investigation plan.

Under the Federal Facility Agreement and Consent Order, the Corrective Action Investigation Plan will be submitted to the Nevada Division of Environmental Protection for approval. Field work will be conducted following approval of the plan. The results of the field investigation will support a defensible evaluation of corrective action alternatives in the Corrective Action Decision Document. 


\subsection{Introduction}

This Corrective Action Investigation Plan (CAIP) has been developed in accordance with the Federal Facility Agreement and Consent Order (FFACO) that was agreed to by the U.S. Department of Energy, Nevada Operations Office (DOE/NV); the State of Nevada Division of Environmental Protection (NDEP); and the U.S. Department of Defense (FFACO, 1996). The CAIP is a document that provides or references all of the specific information for investigation activities associated with Corrective Action Units (CAUs) or Corrective Action Sites (CASs). According to the FFACO (1996), CASs are sites potentially requiring corrective action(s) and may include solid waste management units or individual disposal or release sites. Corrective Action Units consist of one or more CASs grouped together based on geography, technical similarity, or agency responsibility for the purpose of determining corrective actions.

This CAIP contains the environmental sample collection objectives and the criteria for conducting site investigation activities at CAU No. 407, the Roller Coaster RADSAFE Area (RCRSA) which is located on the Tonopah Test Range (TTR). The TTR, included in the Nellis Air Force Range Complex, is approximately 255 kilometers $(\mathrm{km})$ (140 miles [mi]) northwest of Las Vegas, Nevada (Figure 1-1). Corrective Action Unit No. 407 is comprised of only one CAS (No. TA-23-001TARC).

The RCRSA is located on the northeast corner of the intersection of Main Road and Browne's Lake Road which is approximately $8 \mathrm{~km}$ ( $5 \mathrm{mi}$ ) south of Area 3 (Figure 1-2). The RCRSA was used during May and June 1963 to decontaminate vehicles, equipment, and personnel from the Clean Slate tests. The surface and subsurface soils are likely to have been impacted by plutonium and other COPCs associated with decontamination activities at this site.

\subsection{Purpose}

This CAIP presents a plan to investigate the RCRSA. The purpose of the corrective action investigation described in this CAIP is to:

- Identify the presence and nature of COPCs. 


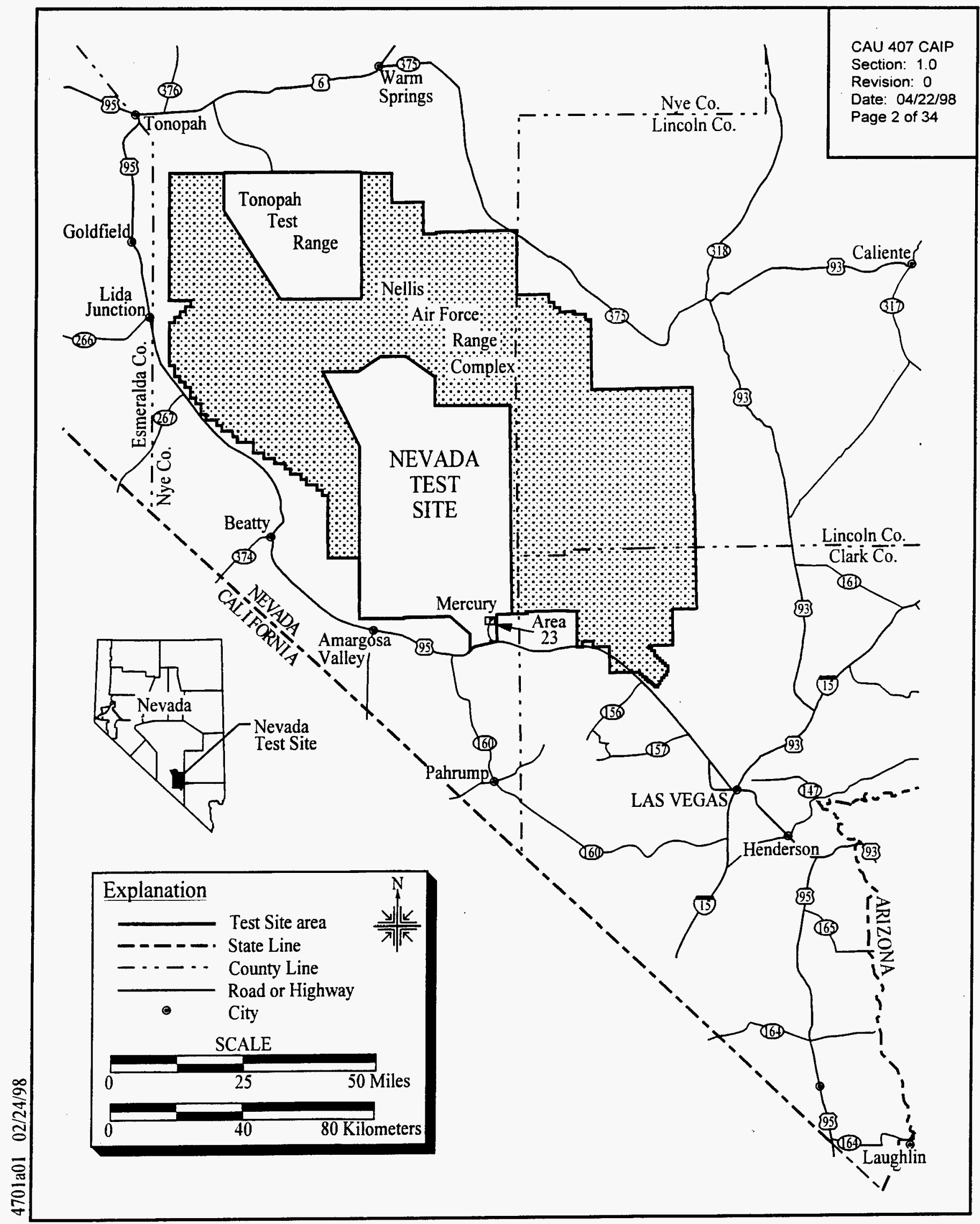

Figure 1-1

Tonopah Test Range Location Map 
- Determine the vertical and lateral extent of COPCs.

- Provide sufficient information and data to develop and evaluate appropriate corrective actions for the CAS.

This CAIP was developed using the U.S. Environmental Protection Agency (EPA) Data Quality Objectives (DQOs) (EPA, 1994) process to clearly define the goals for collecting environmental data. to determine data uses, and to design a data collection program that will satisfy these goals and uses. A DQO scoping meeting was held prior to preparation of this plan; a brief summary of the DQOs is presented in Section 3.4. A more detailed summary of the DQO process and results is included in Appendix A.

\subsection{Scope}

The scope of this CAIP is to resolve the problem statement identified in the DQO process (see Appendix A) which is: radioactive wastes and possibly hazardous wastes were disposed of at the RCRSA, and existing data are insufficient to support selection of a corrective action for the CAU. Therefore, the scope of the corrective action investigation at the RCRSA includes the following tasks that must be accomplished to answer the problem statement:

- Survey the area with appropriate electromagnetic and/or other geophysical equipment to identify potential buried metalic objects and to verify the assumed locations of the vehicle and personnel decon areas, the decon sumps, and the waste disposal pit.

- Drill boreholes using a sonic drilling method or other suitable methods capable of reaching the expected vertical extent of COPCs, of penetrating potential subsurface geologic and project related anomolies (e.g., caliche, gravel, or buried waste), and of providing suitable core for sample collection and logging of subsurface conditions.

- Conduct field screening to direct drilling and sampling activities and provide an initial assessment of the subsurface soil conditions. Potential limitations in field screening capabilities for radionuclides will be addressed through laboratory analysis.

- Collect soil samples for laboratory analysis of environmental and geotechnical parameters.

The geophysical investigation will minimize and help direct the required intrusive investigation. 


\subsection{CAIP Contents}

Section 1.0 of this CAIP provides an introduction to this project. including the purpose and scope for this corrective action investigation. The remainder of the document details the investigation strategy and complies with FFACO (1996) requirements that CAIPs address the following elements:

- Management

- Technical aspects

- Quality assurance

- Health and safety

- Public involvement

- Field sampling

- Waste management

The managerial aspects of this project are discussed in the DOE/NV Project Management Plan (DOE/NV, 1994b) and the site-specific Field Management Plan will be developed prior to field activities. The technical aspects of this CAIP are contained in Section 3.0 and Section 4.0 of this document and in the DQO summary presented in Appendix A. General field and laboratory quality assurance and quality control (QA/QC) issues, including collection of $\mathrm{QC}$ samples, are presented in the Industrial Sites Quality Assurance Project Plan (QAPP) (DOE/NV, 1996d); the methods for field $\mathrm{QA} / \mathrm{QC}$ are discussed in approved procedures. The health and safety aspects of this project are documented in the Environmental Restoration Project Health and Safety Plan (HASP) (DOE/NV, 1996b) and will also be supplemented with a site-specific HASP written prior to the start of field work. No CAU-specific public involvement activities are planned at this time; however, an overview of public involvement is documented in the "Public Involvement Plan" in Appendix V of the FFACO (1996). Field sampling activities are discussed in Section 4.0 of this CAIP; waste management issues are discussed in Section 5.0. The project schedule and records availability information for this CAIP are discussed in Section 6.0, and Section 7.0 provides a list of project references. 


\subsection{Facility Description}

\subsection{Physical Setting}

The RCRSA is approximately $8 \mathrm{~km}(5 \mathrm{mi})$ south of Area 3 at the intersection of Main Road and Browne's Lake Road. The site is approximately $180 \mathrm{~m}$ by $180 \mathrm{~m}(600 \mathrm{ft}$ by $600 \mathrm{ft})$ with the area of COPC currently fenced. The site is bounded on the south and west by paved roads and on the north and east by high desert (IT, 1997b).

The RCRSA is located on a broad, intermontaine basin covered almost entirely by gently east-sloping alluvial material shed from the adjacent volcanic highlands (mostly from the Cactus Range to the west). The elevation at the site is approximately $1,693 \mathrm{~m}(5,558 \mathrm{ft})$ above sea level (Rodriguez, 1997). The depth to water below ground surface (bgs) is approximately $120 \mathrm{~m}$ (400 ft) (DOE/NV, 1994c). The alluvial, groundwater flow direction is generally north-northeast.

The site is comprised of disturbed soils with sparse vegetation. The near-surface alluvium at the site has never been studied in geologic detail; however it is likely to be similar to alluvial fans within the vicinity. Underlying a layer of thin, fine, loamy soil, a silty sand containing abundant gravel and cobbles is likely to be encountered. Localized caliche development is not expected to be present in the near surface and is not observed in the nearby TTR Sandia \#8 well drilled to the north of this CAU (DOE/NV, 1994c).

\subsection{Operational History}

Project Roller Coaster consisted of four noncritical tests of a nuclear device: Double Tracks and Clean Slates No. 1, 2, and 3. The Clean Slates shots were conducted at Cactus Flat, and the Double Tracks shot was conducted in Stonewall Flat, approximately $32 \mathrm{~km}$ (20 mi) east of Goldfield, Nevada (Reynolds Electrical \& Engineering Company, Inc. [REECo], 1963). The Double Tracks test used a single device containing plutonium and depleted uranium (DU). Clean Slate No. 1 had nine devices, one with plutonium and eight without (DU only). Clean Slates No. 2 and No. 3 had 19 devices each: one with plutonium (at each site) and 18 (at each site) without (DU only). All four Roller Coaster tests occurred during May and June of 1963 (REECo, 1963). 
The RCRSA was used to decontaminate vehicles, equipment, and personnel involved in the Clean Slate tests. Ten dogs and ten sheep exposed during Clean Slate 2 may have been decontaminated here as well. All facilities associated with this operation were removed. Based upon available information, the assumed area of concern at this site includes the former hotline area (personnel decon area), the vehicle decon area, two decon sumps, and the waste disposal pit (Figure 2-1) because radioactive waste possibly containing other COPCs was discharged here as part of the operations.

The former hotline area consisted of a trench 0.6 to $0.9 \mathrm{~m}$ ( 2 to $3 \mathrm{ft}$ ) deep filled with gravel which served as a french drain for water used during the doffing of anticontamination clothing and personal protective equipment (PPE) worn by personnel involved in the Clean Slate tests. The vehicle decon area (east of the hotline area) consisted of a pit 1.2 to $1.8 \mathrm{~m} \mathrm{(4} \mathrm{to} 6 \mathrm{ft}$ ) deep filled with gravel which served as a french drain for vehicle decon water. The water that was used came from a tank mounted on a vehicle equipped with a pressure washer. The water then drained from the vehicle decon area into the decon sumps (one primary, one secondary) to the east. A waste disposal pit is believed to be located just east of the two decon sumps (Sygitowicz, 1997). Solid waste and contaminated debris were brought back to the RCRSA along with waste from the decontamination operations and were placed in this pit. After operations, the gravel from the hotline was removed and placed in the pit; the hotline was backfilled. The vehicle decon area, the sumps, and the pit were covered with several feet of clean earth, fenced, and posted (REECo, 1963). No operations are known to have occurred at this site since the Roller Coaster tests in 1963 (Rarrick, 1993).

\subsection{Waste Inventory}

Operations at the RCRSA were sometimes conducted on a 24-hour basis during the two months the site was used. The volumes and types of hazardous waste disposed at the site were not documented; however, interviews indicate that methyl ethyl ketone (MEK) and alcohol-contaminated swabs from deconning of facemasks were disposed of in the waste disposal pit (Sygitowicz, 1997). Additionally, lead-acid batteries were deconned at the vehicle decon area, and the potential exists for some of these batteries to have been directly buried here. 


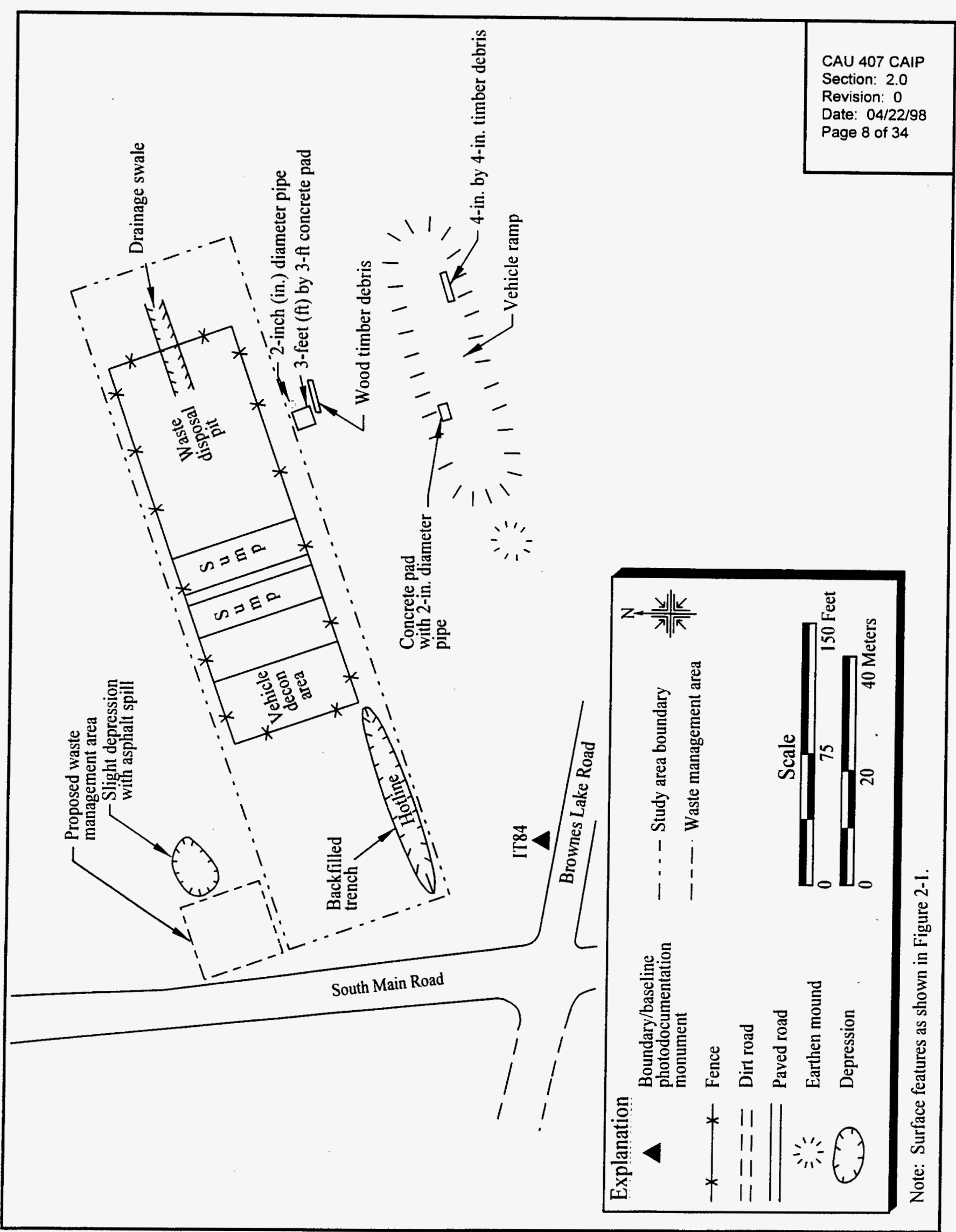

Figure 2-1

Site Location Map, Roller Coaster RADSAFE Area, Tonopah Test Range, Nye County, Nevada 


\subsection{Release Information}

The COPCs were released directly to the soils at the RCRSA as a result of personnel and vehicle decontamination and waste burial. The COPCs in the waste disposal pit may have been distributed across the surface of the RCRSA through grading activities following removal of a metal base plate used at ground zero for the Double Tracks event (IT, 1997b). Subsurface COPCs are a result of direct release to the soil and subsequent migration through natural processes. Migration is assumed to be minor due to the arid climate and high evaporation. Exact quantities of liquids released to the RCRSA are unknown. The exact amount and type of debris and solid waste disposed to the pit are also unknown.

\subsection{Investigative Background}

No surface or subsurface sampling has been conducted at the RCRSA to date. A radiation survey was performed by REECo in January 1966 to detect surface radiation around and within the RCRSA exclusion fence. No surface contamination was detected (REECo, 1966).

Geophysical surveys conducted at the site by IT Corporation (IT, 1997a) include an electromagnetic survey performed on July 23, 1993, and magnetic and ground-penetrating radar (GPR) surveys performed on July 30, 1993. The magnetic and electromagnetic surveys were conducted in a 0.16-hectare (0.4-acre) area off the southwestern corner of the fenced area to investigate a small depression (believed to be the hotline) on this site (Figure 2-2). Three GPR traverses were conducted over the depression. No pits or trenches containing metallic debris were identified within the surveyed area; however, several signals interpreted as pipes were detected and are shown on Figure 2-2.

Additional geophysical investigations (SAIC,1998) and a radiation survey were conducted by Science Applications International Corporation (SAIC) for IT Corporation (IT) between January and March 1998. Geophysical techniques used during this investigation consisted of magnetometer, electromagnetic (EM-31 and EM-61), and ground-penetrating radar (GPR) methods. Figure 2-3 is a geophysical survey location map of the RCRSA and relative cultural features during the 1998 surveys. 


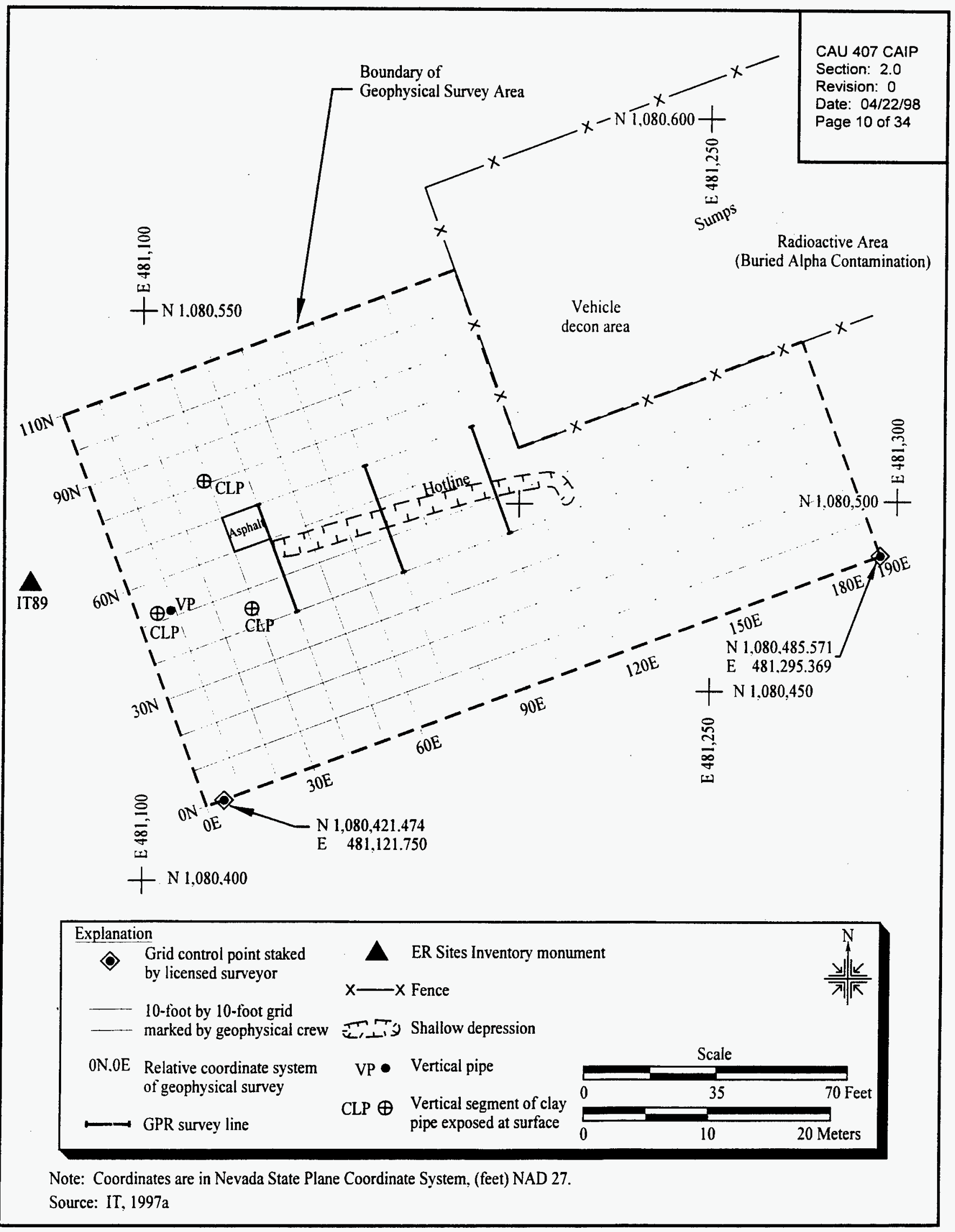

Source: IT, 1997a

Figure 2-2

Roller Coaster RADSAFE Area 1993 Geophysical Survey Location Map, Tonopah Test Range 


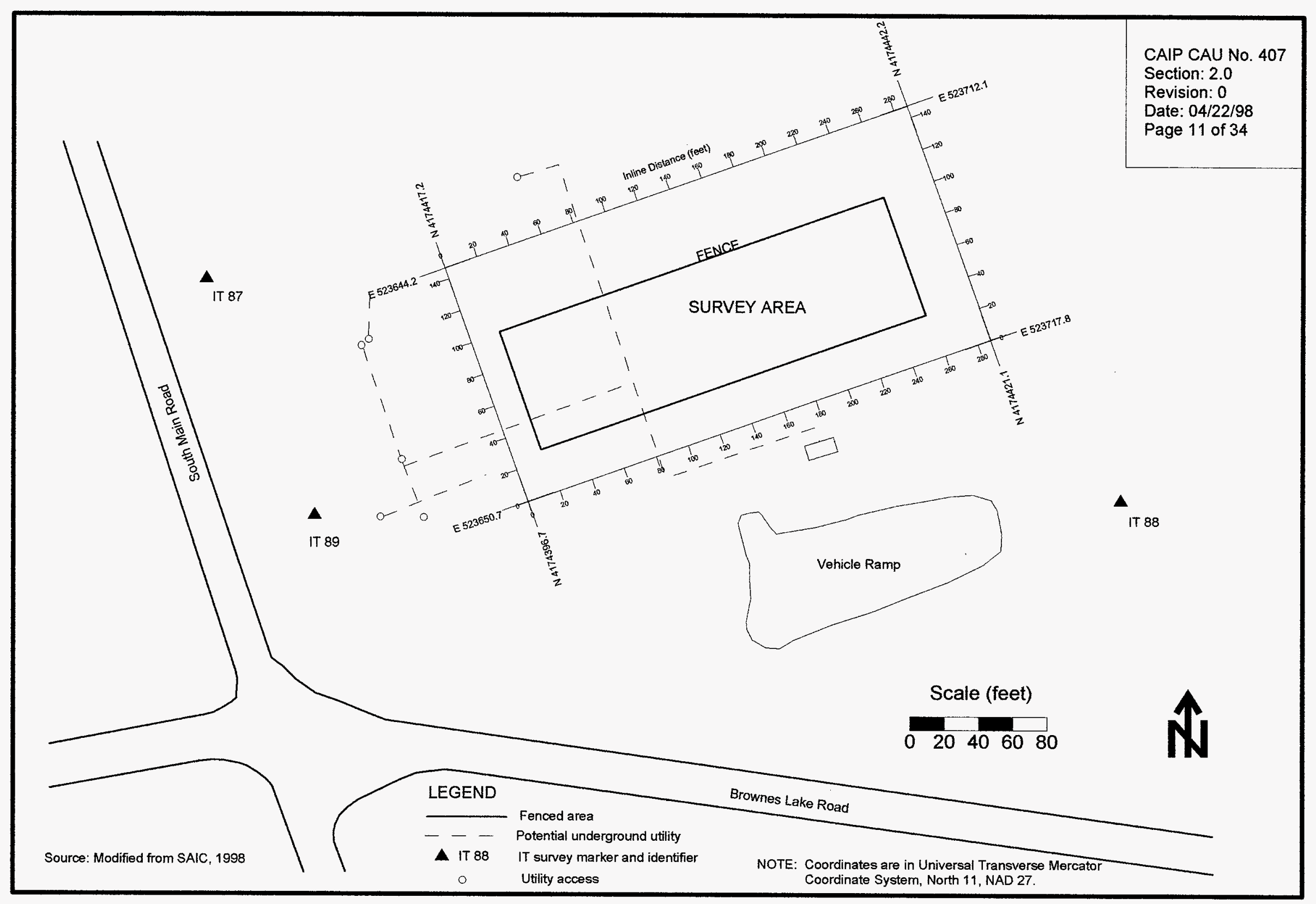

Figure 2-3

Roller Coaster RADSAFE Area 1998 Geophysical Survey Location Map, Tonopah Test Range 
The EM-61 survey shown on Figure 2-4 shows the "L" shape of the remaining portion of the fence that remained intact during the survey. A north/south trending pipe feature is seen at a distance of $24 \mathrm{~m}(80 \mathrm{ft})$ from the zero coordinate and appears to get deeper to the north. The westerly trending anomaly at a distance of $12 \mathrm{~m}(40 \mathrm{ft})$ is also interpreted as a pipe-like feature. Two nearly closed elevated response features are also present and are consistent with the responses that would be expected from waste pits. Just northwest of the juncture of the pipe-like features are isolated anomalous features. These may represent a waste pit; however, the data indicates these features are smaller and more discontinuous than the other waste pit features.

Following collection of the EM-61 data, an evaluation was performed using this equipment in an effort to trace the pipe-like features. The western trending pipe-like feature continued west to a place where a clay pipe is observed at the ground surface. Tracing farther, a line appeared to trend north to south from this location to where additional clay pipes are observable at the surface.

Other geophysical surveys confirmed the EM- 61 survey findings. The GPR was evaluated using 100-, 200-, 300-, and 500-megahertz (mHz) antennas within the fenced area. The 300- and 500-mHz antennas do not appear to have a depth of penetration necessary to evaluate the features of concern. The best information appeared to be from the $100-$ and $200-\mathrm{mHz}$ antennas. The $100-\mathrm{mHz}$ antenna has some problem with air waves (caused by running over brush at the site). Additionally, data was collected with a deep setting, which tended to mask subtle near-surface features that have been found to be important. The $200-\mathrm{mHz}$ antenna provided the best overall data suite; however, the GPR surveys did not show the boundaries of the sumps, waste disposal pit, or the vehicle decon area. 


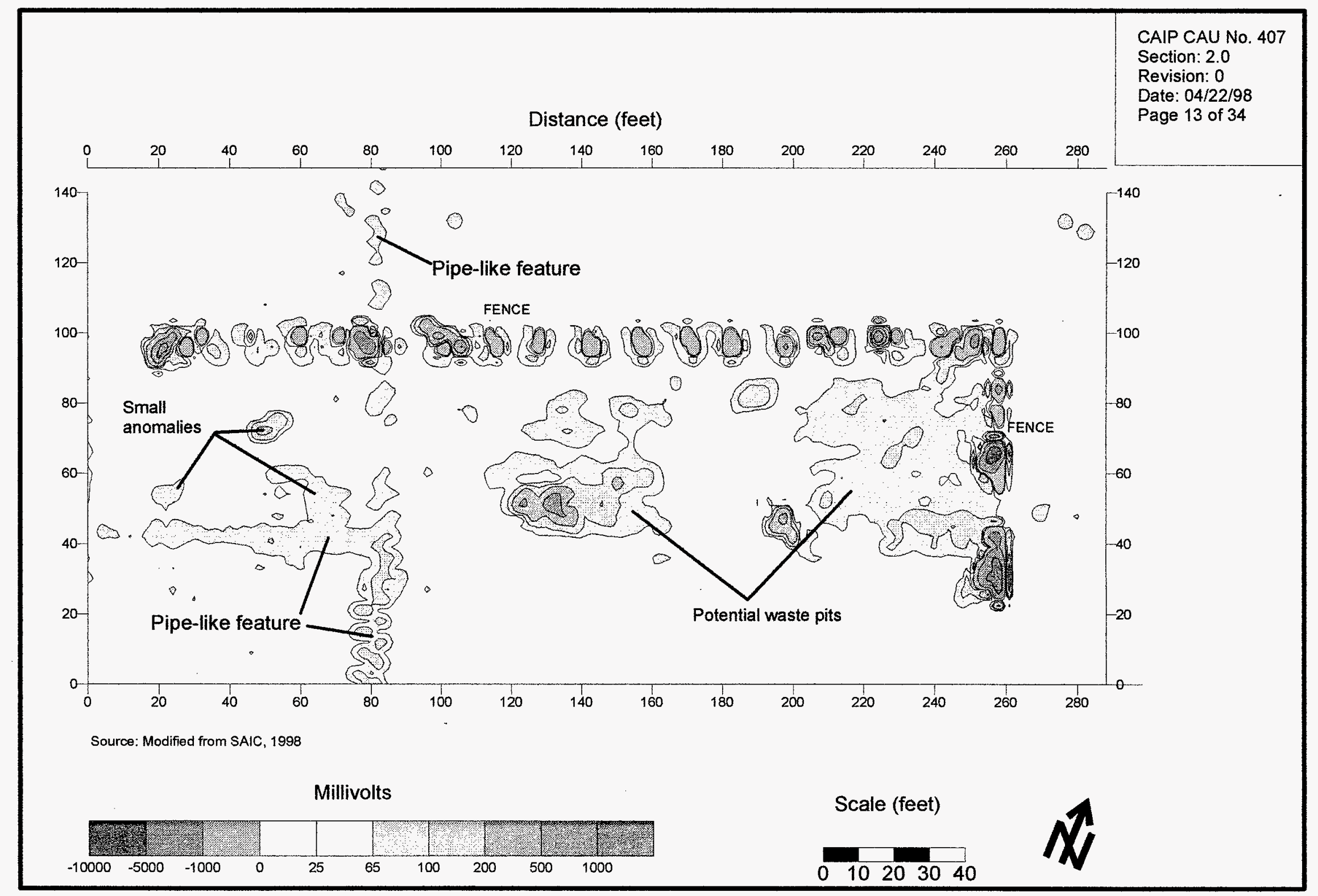

Figure 2-4

Roller Coaster RADSAFE Area EM-61 Survey 


\subsection{Objectives}

The DQOs are qualitative and quantitative statements that specify the quality of the data required to support potential courses of action for the RCRSA. The DQOs were developed to clearly define the purposes for which environmental data will be used and to design a data collection program that will satisfy these purposes. One element of the DQO process is the formulation of a conceptual site model.

\subsection{Conceptual Site Model}

The conceptual site model for the RCRSA developed in the DQO process is presented in Appendix A and is summarized as follows:

- COPCs associated with the decontamination fluids were released into the soil at the hotline, vehicle decon area, and the two decon sumps (Figure 2-1).

- COPCs are limited vertically to less than 9-m (30-ft) and horizontally to less than 3-m (10-ft) from the bottom and sides of the two decon sumps and the vehicle decon area.

- COPCs associated with debris and solid waste were disposed of in the waste disposal pit.

- Semivolatile organic compounds and hydrocarbons originating from vehicle decon activities are at low concentrations.

Groundwater impact is unlikely because depth to groundwater is extensive (greater than $120 \mathrm{~m}$ [400 ft]) (DOE/NV, 1996b), and the environmental conditions at the site (i.e., arid climate, high evaporation) are not conducive to downward migration of COPCs.

\subsection{Contaminants of Potential Concern}

The following is the list of COPCs based on process knowledge:

- Plutonium

- Depleted uranium

- Volatile organic compounds (VOCs)

- Semivolatile organic compounds (SVOCs) 
- Metals

- Total petroleum hydrocarbons (TPHs)

Radionuclides other than plutonium and depleted uranium, pesticides, and polychlorinated biphenyls (PCBs) are COPCs based on related activity sites (pesticides were identified at Roller Coaster Sewage Lagoon, CAU 404) or as a precautionary measure.

\subsection{Preliminary Action Levels}

Preliminary action levels for both on-site field screening methods and off-site analytical methods will be used to determine the presence of contamination. The following action levels will be used for on-site field screening:

- Volatile organic compound headspace screening levels at 20 parts per million (ppm) or 2.5 times background, whichever is greater

- Radiation (alpha and beta/gamma) screening above two times the established daily background

Field screening concentrations exceeding preliminary action levels for radionuclides indicate potential contamination at that sample location. This information will be documented, and the investigation will be continued to delineate the extent of the contamination. Additionally, this data may also be used to select discretionary samples to be submitted to the laboratory.

Off-site laboratory analytical results will be compared to the following preliminary action levels to evaluate the need for possible corrective actions:

- NDEP Corrective Action Regulations (NAC, 1996a)

- TPH concentrations above the TPH limit of 100 ppm per the Nevada Administrative Code (NAC) 445A.2272 (NAC, 1996a)

- Background concentrations of radioactive material or concentrations above those listed in the Offsite Radiation Exposure Review Project, Phase II Soils Programs report (McArthur and Miller, 1989)

Laboratory results will be compared to preliminary action levels in the Corrective Action Decision Document (CADD). Laboratory results above action levels indicate the presence of COPCs at levels 
that may require corrective action. The evaluation of potential corrective actions and the justification for a preferred action will be included in the CADD based on the results of this field investigation. Proposed cleanup levels will be determined during the CADD.

\subsection{DQO Process Discussion}

Details of the DQO process are presented in Appendix A. The DQO results for the RCRSA indicated the need for a biased sampling approach. Due to potential subsurface migration of COPCs, an investigation consisting of subsurface sampling was identified. The COPCs, analytical methods, and reporting limits prescribed through the DQO process are provided in Table 3-1. The precision and accuracy requirements are those stated in the latest revision of the individual EPA SW-846 methods (EPA, 1996b). Representativeness for the investigation and resulting data will be evaluated by confirming or refuting the conceptual model.

Table 3-1

Laboratory Analytical Requirements

(Page 1 of 2)

\begin{tabular}{|c|c|c|c|c|c|}
\hline Analyte & Medium & $\begin{array}{l}\text { Analytical } \\
\text { Method }\end{array}$ & $\begin{array}{c}\text { Minimum } \\
\text { Reporting Limit }\end{array}$ & $\begin{array}{l}\text { Precision } \\
\text { (RPD) }\end{array}$ & $\begin{array}{c}\text { Accuracy } \\
\text { (\%R) }\end{array}$ \\
\hline \multirow{2}{*}{ Total VOCs } & Water & \multirow{2}{*}{$8260^{c}$} & \multirow{2}{*}{$\begin{array}{c}\text { Analyte-specific } \\
\text { estimated quanitation } \\
\text { limits }^{d}\end{array}$} & 14 & $60-132$ \\
\hline & Soil & & & 24 & $59-172$ \\
\hline \multirow{2}{*}{ Total SVOCs } & Water & \multirow{2}{*}{$8270^{c}$} & \multirow{2}{*}{$\begin{array}{l}\text { Analyte-specific } \\
\text { estimated quanitation } \\
\text { limits }^{d}\end{array}$} & 50 & $5-230$ \\
\hline & Soil & & & 50 & $11-142$ \\
\hline \multicolumn{6}{|c|}{ Total RCRA Metals } \\
\hline Arsenic & & & $10 \mu \mathrm{g} / \mathrm{L}$ & & \\
\hline Barium & & & $200 \mu g / L$ & & \\
\hline Cadmium & & & $5 \mu \mathrm{g} / \mathrm{L}$ & & \\
\hline Chromium & Water & $6010 / 7470^{c}$ & $10 \mu \mathrm{g} / \mathrm{L}$ & 20 & $75-125$ \\
\hline Lead & & & $3 \mu \mathrm{g} / \mathrm{L}$ & & \\
\hline Mercury & & & $0.2 \mu \mathrm{g} / \mathrm{L}$ & & \\
\hline Selenium & & & $5 \mu \mathrm{g} / \mathrm{L}$ & & \\
\hline Silver & & & $10 \mu \mathrm{g} / \mathrm{L}$ & & \\
\hline
\end{tabular}


Table 3-1

Laboratory Analytical Requirements

(Page 2 of 2)

\begin{tabular}{|c|c|c|c|c|c|}
\hline Analyte & Medium ${ }^{a}$ & $\begin{array}{l}\text { Analytical } \\
\text { Method }\end{array}$ & $\begin{array}{l}\text { Minimum } \\
\text { Reporting Limit }\end{array}$ & $\begin{array}{l}\text { Precision } \\
\text { (RPD) }\end{array}$ & $\begin{array}{c}\text { Accuracy } \\
(\% R)\end{array}$ \\
\hline $\begin{array}{c}\text { Total RCRA Metals } \\
\text { Arsenic } \\
\text { Barium } \\
\text { Cadmium } \\
\text { Chromium } \\
\text { Lead } \\
\text { Mercury } \\
\text { Selenium } \\
\text { Silver }\end{array}$ & Soil & $6010 / 7470^{\circ}$ & $\begin{array}{c}1 \mathrm{mg} / \mathrm{kg} \\
20 \mathrm{mg} / \mathrm{kg} \\
0.5 \mathrm{mg} / \mathrm{kg} \\
1 \mathrm{mg} / \mathrm{kg} \\
0.3 \mathrm{mg} / \mathrm{kg} \\
0.1 \mathrm{mg} / \mathrm{kg} \\
0.5 \mathrm{mg} / \mathrm{kg} \\
1 \mathrm{mg} / \mathrm{kg}\end{array}$ & 20 & $75-125$ \\
\hline \multirow{2}{*}{$\begin{array}{l}\text { Total Pesticides and } \\
\text { PCBs }\end{array}$} & Water & \multirow{2}{*}{$8080^{C}$} & \multirow{2}{*}{$\begin{array}{c}\text { Analyte specific } \\
\text { estimated quantitation } \\
\text { limit }\end{array}$} & 30 & $8-160$ \\
\hline & Soil & & & 50 & $8-139$ \\
\hline \multirow{4}{*}{$\mathrm{TPH}$} & Water (gasoline) & \multirow{4}{*}{8015 modified $^{c}$} & $1 \mathrm{mg} / \mathrm{L}$ & 20 & $25-145$ \\
\hline & Water (diesel) & & $0.5 \mathrm{mg} / \mathrm{L}$ & 20 & $25-145$ \\
\hline & Soil (gasoline) & & $0.5 \mathrm{mg} / \mathrm{kg}$ & 30 & $30-130$ \\
\hline & Soil (diesel) & & $25 \mathrm{mg} / \mathrm{kg}$ & 30 & $30-130$ \\
\hline \multirow{2}{*}{$\begin{array}{l}\text { Gamma-Emitting } \\
\text { Radionuclides }\end{array}$} & Water & EPA $901.1^{\mathrm{e}}$ & $20 \mathrm{pCi} / \mathrm{L}$ & 20 & $80-120$ \\
\hline & Soil & HASL $300,4.5 .2 .3^{f}$ & $0.2 \mathrm{pCi} / \mathrm{g}$ & 20 & $80-120$ \\
\hline \multirow{2}{*}{ Isotopic Plutonium } & Water & NAS-NS $3058^{9}$ & $0.5 \mathrm{pCi} / \mathrm{L}$ & 25 & $75-125$ \\
\hline & Soil & NAS-NS 3058 & $0.5 \mathrm{pCi} / \mathrm{g}$ & 25 & $75-125$ \\
\hline \multirow{2}{*}{$\begin{array}{l}\text { Isotopic Uranium } \\
\left(\mathrm{U}^{230}\right)\end{array}$} & Water & \multirow{2}{*}{$\begin{array}{l}\text { NAS-NS- } 3050^{9} \text { or } \\
\text { LAL-91-SOP-0108 }\end{array}$} & \multirow{2}{*}{$\begin{array}{l}\text { Background Levels or } \\
\text { ORERP }\end{array}$} & \multirow{2}{*}{$25^{j}$ or 20} & \multirow{2}{*}{$\begin{array}{c}70-120^{\mathrm{j}} \text { or } \\
70-130\end{array}$} \\
\hline & Soil & & & & \\
\hline
\end{tabular}

'QC (water) samples are included in table

Industrial Sites Quality Assurance Project Plan (DOE/NV, 1996d)

'EPA Test Methods for Evaluating Solid Waste. 3rd Edition. Parts 1-4. SW-846 (EPA, 1996b)

'Estimated Quantitation Limit (EQL) as given in Method SW-846, U.S. EPA (EPA, 1996b)

- Prescribed Procedures for Measurement of Radioactivity in Drinking Water (EPA, 1980)

'Environmental Measurements Laboratory Procedures Manual, HASL-300, U.S. Department of Energy (DOE, 1992)

- National Academy of Science. Nuclear Science Series, September 1963

"Offsite Radiation Exposure Review Project (ORERP), Phase // Soils Program report (DOE/NV/10384-23) (McArthur and Miller, 1989)

'LAS Laboratory, 1993, Standard Operating Procedures

IPrecision and Accuracy requirements were obtained from the Streamiined Approach for Environmental Plan, CAU No. 400: Bomblet Pit and Five Points Landfill (DOE/NV, 1996e)

$\mathrm{mg} / \mathrm{kg}=$ Milligram(s) per kilogram

pCi/L = Picocurie(s) per liter

$\mathrm{mg} / \mathrm{L}=$ Milligram(s) per liter

pCi/g = Picocurie(s) per gram

$\mu \mathrm{g} / \mathrm{L}=$ Microgram(s) per liter

RCRA = Resource Conservation and Recovery Act 


\subsection{Field Investigation}

This section of the CAIP contains the sampling approach for investigating the Roller Coaster RADSAFE Area. All sampling activities will be conducted in compliance with the Industrial Sites QAPP (DOE/NV, 1996d) and other applicable, approved procedures. Quality assurance and quality control requirements for field and laboratory environmental sampling are also contained in the Industrial Sites QAPP (DOE/NV, 1996d) and in Table 3-1.

Geophysical surveys conducted during the preliminary investigation of CAU 407 were used to guide the technical approach for planned surface and subsurface sampling events. The GPR survey was used to identify the probable location of the vehicle decontamination area, sumps, and waste disposal pit. In addition, the electromagnetic survey was used to determine the most likely location of the waste disposal pit and other excavations containing buried metal.

\subsection{Technical Approach}

The following activities will be executed during the site investigation:

- Drill boreholes at potential contamination release sites.

- Conduct field screening for radiological constituents and VOCs.

- Collect surface and subsurface environmental samples.

- Collect geotechnical surface and subsurface samples.

- Collect background surface and subsurface samples.

- Collect required quality control samples.

\subsubsection{Soil Borings}

At least five boreholes will be required to define subsurface conditions and subsequently distinguish between the primary and alternate potential contamination models established during the DQO process. These boreholes will be drilled along a roughly southwest to northeast traverse through likely contamination release locations at the site as shown in Figure 4-1. Boreholes will be drilled at the assumed locations of the hotline, vehicle decontamination area, the western decontamination sump, the waste disposal pit, and the drainage swale at the east end of the fenced area. 


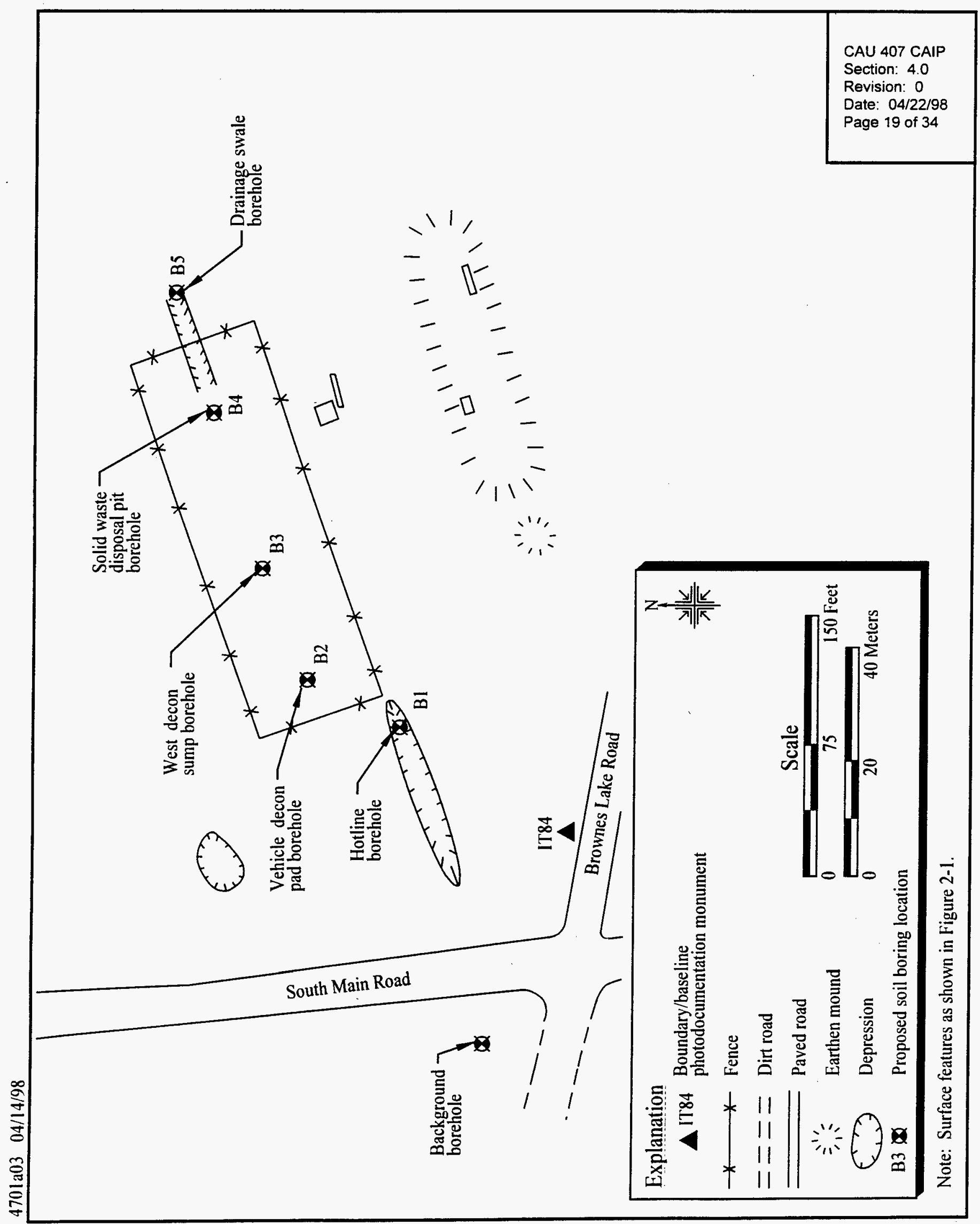

Figure 4-1

Proposed Soil Boring Locations, Roller Coaster RADSAFE Area, Tonopah Test Range, Nye County, Nevada 
The boreholes will be drilled to a minimum depth of $9 \mathrm{~m}(30 \mathrm{ft})$. These boreholes should adequately constrain potential vertical contamination at the site, but additional step-out borings may be drilled, based on the results of the initial borings and at the discretion of the Site Supervisor, to further delineate the lateral extent of COPCs. Step-out borings will be drilled in the same manner as the initial borings.

Dry sonic drilling will be used to advance the boreholes. This method provides continuous core for environmental sample collection and geologic description. Advantages of sonic drilling include minimal derived waste for a given sample volume; high-quality, relatively undisturbed samples; and the ability to penetrate substantial gravel fill and most solid waste (e.g., metal, concrete, other construction debris) that may be buried in the solid waste pit. In addition, the continuous core produced with this method should allow the fill material and native soil interface depth to be determined.

All borings will be filled to the ground surface with bentonite grout upon completion of sampling activities. The grouting of the boreholes will be postponed if field-screening methods are not capable of detecting the maximum vertical extent of COPCs (i.e., plutonium and/or daughter products). Borings will be adequately protected during this time to prevent materials from entering the open hole. Open boreholes will be continued or grouted after the laboratory results are returned.

\subsubsection{Field Screening}

Field screening for radiation and VOCs will be conducted for all borings and will provide information to establish the required maximum drilling depth for each borehole and the need for step-out borings. If field-screening results exceed the preliminary action levels listed in Section 3.3, drilling will continue until two consecutive results below these levels are recorded. The field-screening methods will consist of radiological screening using an instrument such as a FIDLER (field instrument for the detection of low energy radiation) or a microroetgen meter for alpha and beta/gamma emitters and headspace testing for VOCs. Field screening will be performed at $0.76-\mathrm{m}(2.5-\mathrm{ft})$ intervals to approximately $9 \mathrm{~m}(30 \mathrm{ft}$ ) bgs. If drilling continues beyond this depth, field screening will continue in $1.5-\mathrm{m}(5-\mathrm{ft})$ intervals to total depth. 
Field-screening data will serve three purposes. First, the data will provide continuous semiquantitative measurement of the subsurface conditions. Second, the data will provide a mechanism for guiding the depth of the investigation. Third, the data may be used to aid the selection of samples to be submitted for laboratory analysis.

\subsubsection{Environmental Samples}

Environmental samples will be collected in $1.5-\mathrm{m}(5-\mathrm{ft})$ intervals beginning at the surface and continuing for the entire length of each boring. Samples from $7.6 \mathrm{~m}(25 \mathrm{ft})$ and $9 \mathrm{~m}(30 \mathrm{ft})$ bgs (the assumed deepest two samples for a given borehole) will be submitted to the laboratory to bound the vertical extent of contamination and verify field-screening results for each individual boring. Additionally, a sample from the interval with the highest field-screening measurement will be submitted for laboratory analysis. Samples submitted to the laboratory will be analyzed in accordance with Table 3-1.

Beginning at the interface between the fill material and the native soil, an increased sampling frequency will be used, as core recovery allows, up to $0.3-\mathrm{m}(1-\mathrm{ft})$ intervals and up to five samples. These samples will be field screened and sent to the laboratory and analyzed for radionuclides only. This interface should be apparent in the boring through the vehicle decontamination pad, but may be difficult to recognize in borings penetrating features where no gravel was present (i.e., solid waste pit) or was removed (i.e., hotline). If this interface is difficult to recognize, the increased sampling interval will be used from the anticipated interface for each individual sampling site to obtain vertical definition of COPC extent to support evaluation in the CADD. The boring at the drainage swale will only be sampled every $1.5 \mathrm{~m}(5 \mathrm{ft})$ due to the lack of fill material and the interface. Additional samples may be collected at the discretion of the Site Supervisor.

All equipment which contacts soil to be sampled will be decontaminated in accordance with contractor's written and approved procedures consistent with the Environmental Restoration Division Procedure ERD-05-701, "Sampling Equipment Decontamination," Rev. 0 (DOE/NV, 1994c), or as appropriate for special equipment being decontaminated (i.e., decontaminating core barrels). Core barrels will be decontaminated prior to each sampling event to minimize the potential for cross-contamination of samples from different sample locations or depths. 
Environmental samples collected for laboratory analysis will be samples of fresh (unused) media. Samples will be collected with highest priority given to those that will be analyzed for VOCs. When volatilization of COPCs is not a concern, samples will be collected with priority given to those with the shortest hold times prior to analysis.

The analytes, analytical methods, and associated quality control ranges for precision and accuracy measurements of samples submitted to the laboratory are specified in Table 3-1. Records will be maintained for a visual classification of the soil. field-screening measurements, and all other relevant data. Pertinent and required sampling information (e.g., date, time, sample interval) will be documented in accordance with the Industrial Sites QAPP (DOE/NV, 1996d). Approved chain of custody procedures (DOE/NV, 1994a) will be followed to assure data defensibility.

\subsubsection{Quality Control Samples}

Quality control samples will be collected as required by the Industrial Sites QAPP (DOE/NV, 1996d). These samples will include trip blanks, equipment blanks, field blanks, field duplicates, and matrix spike/matrix spike duplicate (MS/MSD) samples. Except for trip blanks, all QC samples will be analyzed for applicable parameters in Table 3-1. Trip blanks will only be analyzed for VOCs. One set of QC samples will be collected for every twenty (or fraction of twenty) environmental characterization samples submitted to the laboratory. Additional QC samples may be submitted at the discretion of the Site Supervisor.

\subsubsection{Background Samples}

Background samples will be collected from a background borehole drilled west of the site and the South Main Road (Figure 4-1) in an area not known to have been disturbed by Clean Slate operations. The location is upgradient of the RCRSA. The Clean Slate testing was conducted to the east of the RCRSA. This borehole will be completed and samples will be collected in the same manner as the boreholes described in Section 4.1.1 of this CAIP. Background information will be used to evaluate data for use in the CADD and in the event risk assessment is needed to support the corrective action at this site. 


\subsubsection{Geotechnical Samples}

In addition to environmental samples, geotechnical samples will be collected from both the fill material above the original RCRSA operational features (e.g., gravel vehicle decontamination pad, solid waste pit) and native soil. Analysis of geotechnical parameters listed in Table 4-1 will be performed by an off-site, fixed-base laboratory. The methods shown are minimum standards and other equivalent or superior testing methods may be used.

Table 4-1

Geotechnical Analyses

\begin{tabular}{|c|c|}
\hline Analysis & Method \\
\hline Initial moisture content & ASTM $^{\mathrm{a}}$ D 2216 \\
\hline Dry bulk density & EM $^{\mathrm{D}}-1110-2-1906$ \\
\hline Calculated porosity & EM-1110-2-1906 \\
\hline Saturated/unsaturated hydraulic conductivity & ASTM D 5084 \\
\hline Particle-size distribution & ASTM D 422 \\
\hline Water-release (moisture retention) curve & ASTM D 3152 \\
\hline
\end{tabular}

ASTM, 1996

DUSACE, 1970 


\subsection{Waste Management}

Management of Investigation-Derived Waste (IDW) will be based on regulatory requirements, field observations, process knowledge, and the results of laboratory analysis of RCRSA investigation samples. Decontamination activities will be performed according to approved contractor procedures specified in the contractor field sampling instructions and as appropriate for the COPCs likely to be identified at the RCRSA.

Waste other than soil is potentially contaminated waste only by virtue of contact with potentially contaminated media. Therefore, sampling and analysis of IDW, separate from analyses of site characterization samples, will not be required. The data generated as a result of site characterization and process knowledge will be used to assign the appropriate waste type (i.e., sanitary, hazardous, low-level radioactive [LLW], or mixed) to the IDW with the exception noted in Section 5.3.

Sanitary, hazardous, radioactive, and/or mixed waste, if generated, will be managed and disposed of in accordance with U.S. Department of Energy (DOE) Orders, U.S. Department of Transportation (DOT) regulations, Resource Conservation and Recovery Act (RCRA) regulations, "Nevada Revised Statutes" (NAC, 1996b), and agreements and permits between the DOE and NDEP.

In the following sections, operational requirements are provided for managing sanitary, hazardous, low-level radioactive, and mixed wastes. However, when the waste is initially generated, the waste will be managed according to mixed waste requirements until laboratory analyses are received and a final waste determination is made.

\subsection{Waste Minimization}

Corrective action investigation activities have been planned to minimize IDW generation.

Decontamination activities are planned to minimize the use of rinseate; decontamination materials will consist of detergent, water, and wipes. Waste, such as disposable sampling equipment, decon rinsate, and PPE will be segregated to the greatest extent possible to minimize the generation of hazardous, radioactive, and/or mixed waste. 


\subsection{Potential Waste Streams}

Historical records and process knowledge indicate that potentially hazardous materials were disposed of at the RCRSA. Wastes generated during the investigation activities will include the following:

- Potentially contaminated disposable sampling equipment (such as plastic, paper, sample containers, aluminum foil, spoons, scoops, and bowls) and PPE

- Decontamination rinsate

- Potentially contaminated soil

The waste will be managed in three waste streams; additional segregation will occur within each waste stream based on sample location. Waste will be traceable to its source and to individual samples.

\subsection{Investigation-Derived Waste Management}

To allow for the segregation of radioactive and nonradioactive waste and materials, radiological swipe surveys may be conducted on reusable sampling equipment and the PPE and disposable sampling equipment waste streams exiting from within the controlled area. Removable contamination limits, as defined in Table 2-2 of the DOE NV/YMP Radiological Control Manual (DOENV, 1996c), shall be used to determine if such materials may be declared nonradioactive. Once a radiological or nonradiological disposition has been made for a particular waste stream, a sanitary or hazardous waste disposition will be made. The final disposition of such wastes will be determined by evaluating the analytical results of acquired soil samples. Management requirements for sanitary, low-level, hazardous, or mixed wastes are discussed further in the following sections.

\subsubsection{Sanitary Wastes}

Sanitary waste generated outside the controlled area will be contained in plastic bags and will be transported to a solid waste management unit. Sanitary waste generated within the controlled area will be swiped to determine if the removable contamination is under the limits defined in Table 2-2 of the DOE/NV Radiological Control Manual (DOE/NV, 1996c). Analytical results from the swipe surveys will be used for determining if removable materials will be declared nonradioactive, and 
analytical results from soil sampling will be used for determining if the materials will be declared sanitary.

\subsubsection{Low-Level Waste}

Low-level waste, if generated, will be managed in accordance with the contractor-specific waste certification program plan and the Nevada Test Site Waste Acceptance Criteria (NTSWAC) (DOE/NV, 1997). Waste drums containing soil, PPE and disposable sampling equipment, and rinsate (when full) shall be staged at a designated Radioactive Materials Area pending certification and disposal under NTSWAC requirements (DOE/NV, 1997). Waste drums shall be labeled "Hazardous Waste Awaiting Analysis." All drums shall be locked or fitted with tamper-indicating devices (TIDs). Traceability shall be maintained by assigning unique waste tracking numbers to each container and by maintaining records that trace the IDW back to the original sampling locations.

The PPE and disposable sampling equipment shall be placed in clear plastic bags marked with the date and an associated borehole number. The bags will be tagged with a contractor-specific waste tracking tag and logged in the contractor-specific waste management logbook.

Soil generated during borehole advancement (cuttings) shall be collected in 55-gallon drums with 6-mil liners that meet DOT specifications (49 CFR 17.2) (49 CFR 1997b). Cuttings shall be segregated by borehole. Drums used to contain soil shall be inspected prior to use. If the drum is damaged, cannot be locked, or cannot have a tamper-indicating device placed on it shall not be used. Absorbent Stergo ${ }^{T M}$ pads shall be added to drums of radioactively contaminated soil waste drums. Contractor-specific waste tracking tags shall be used and may be attached to the inside liner, the exterior of the drums, or marked with the drums's unique identification number, and stored with the contractor-specific logbook. The borehole number must be placed on each tracking tag. Drum inspection and absorbent addition shall be documented on appropriate form.

Rinsate shall be collected in 55-gallon drums that meet DOT specifications (49 CFR 172) (49 CFR, 1997b) pending further treatment. Rinsate shall be analyzed separately to determine final disposition. 


\subsubsection{Hazardous Waste}

Suspected hazardous waste will be managed in accordance with RCRA and State of Nevada hazardous waste management regulations, interpreted as follows. Suspected hazardous waste will be placed in 55-gallon drums that meet DOT specifications (49 CFR 172) (CFR, 1997b) which will be locked or fitted with TIDs. The IDW shall be containerized in a manner to comply with Subpart CC of 40 CFR 265 (CFR, 1996b) and the drums shall be compatible with the waste in accordance with the requirements of 40 CFR 265.172 (CFR, 1996b). No incompatible wastes are expected to be generated; however, if incompatible waste is encountered in the field, it will be managed in accordance with 40 CFR 265.177 (CFR, 1996b) (i.e., shall not be placed in the same container) and shall be separated so that in the event of a spill, leak, or release, incompatible wastes shall not contact one another. Drums shall be handled and inspected in accordance with the requirements of 40 CFR 265.173 and 174 , respectively (CFR, 1996b).

Hazardous waste shall be characterized in accordance with the requirements of 40 CFR 261 (CFR, 1996a). Characterization will be based on laboratory results and process knowledge. Drums containing IDW pending characterization will be marked with the words "Hazardous Waste Awaiting Analysis" until its regulatory status can be determined through interpretation and evaluation of laboratory results. The IDW shall be traceable to its source and/or samples considered analogous to the IDW (such as PPE associated with a sample). Traceability shall be maintained by assigning unique waste tracking numbers to each container and by maintaining records that trace the IDW back to the samples. After receipt of analytical results, hazardous wastes, if identified will be labeled and marked in accordance with the requirements of 40 CFR 262.32 (CFR, 1997a) and State of Nevada requirements to include writing the EPA hazardous waste number on the hazardous waste label.

Alpha and gamma spectroscopy are included in the required site characterization analyses to determine if the waste will meet the Nevada Test Site Performance Objectives for Certification of Nonradioactive Hazardous Waste (BN, 1995). These analysis are included in the event the waste generated during site characterization is determined to be a hazardous waste.

Hazardous waste management methods to include the establishment of Satellite Accumulation Areas or a 90-day Hazardous Waste Accumulation Area will be employed to temporarily accumulate IDW 
pending characterization. These methods will be appropriate for the amount of waste being accumulated and in compliance with applicable State of Nevada and federal requirements.

Suspected hazardous waste will be accumulated at or near the site of generation for up to 90 days in accordance with 40 CFR 262.34 (CFR, 1997a). Prior to or on the 90th day of accumulation as specified in 40 CFR 262.34 (a) (CFR, 1997a), hazardous waste will be shipped by a licensed/permitted hazardous waste transporter to a permitted treatment storage and disposal facility. If hazardous waste must remain on-site for longer than 90 days due to unforeseen, temporary, and uncontrollable circumstances, a letter requesting an extension for up to 30 days will be sent to the NDEP in accordance with 40 CFR Part 262.11(b) (CFR, 1997a). A copy of the uniform hazardous waste manifest shall be provided to the State of Nevada.

\subsubsection{Mixed Wastes}

Mixed waste, if generated, shall be managed in accordance with RCRA (40 CFR 262) (CFR, 1997a) and State of Nevada NAC 444 (NAC, 1990). These regulations, as well as DOE requirements for radioactive waste, are interpreted as follows. Where there is a conflict in regulations or requirements, the most stringent shall apply. For example, the 90-day accumulation time limit and weekly inspections per RCRA regulations will be applied to mixed waste even though it is not required for radioactive waste. Conversely, while RCRA does not require documented traceability, the waste acceptance program for LLW does; therefore, traceability shall be documented as described in Section 5.3.2.

In general, mixed waste shall be managed in the same manner as hazardous waste, with added mandatory radioactive waste management program requirements. Suspected mixed waste will be managed in accordance with applicable regulations and requirements and will be marked with the words "Hazardous Waste Awaiting Analysis" pending characterization and confirmation of its regulatory status. However, once the waste determination is made, or the RCRA 90-day time requirement draws to an end, mixed waste shall be transported via a permitted hazardous waste hauler to the Nevada Test Site (NTS) transuranic (TRU) waste storage pad for storage pending treatment or disposal. Mixed waste with hazardous waste constituents below land disposal restrictions may be disposed of at the Area 5 Radioactive Waste Management Site. 
Mixed waste not meeting land disposal restrictions will require development of a treatment plan under the requirements of the Mutual Consent Order between DOE and the State of Nevada (NDEP, 1995). 


\subsection{Duration and Records Availability}

\subsection{Duration}

After the submittal of the CAIP to NDEP (FFACO milestone date of June 30,1998), the following is a tentative schedule of activities (in calendar days):

- Day 0: Preparation for field work will begin.

- Day 60: The field work, including field screening and sampling, will begin. Samples will be shipped to meet lab holding times.

- Day 110: The field work will be completed.

- Day 185: The quality-assured laboratory analytical sample data will be available for review.

- $\quad$ The FFACO date for the CADD is March 31, 1999.

The following information will be reported in the CADD:

- Introduction, including purpose, scope, and a discussion about the need for further action

- Results of the corrective action investigation

- Corrective measures study, including initial screening of alternatives, evaluation of alternatives, and comparison of alternatives

- The recommended alternative

\subsection{Records Availability}

Historic information and documents referenced in this plan are retained in the DOE/NV project files in Las Vegas, Nevada, and can be obtained through written request to the DOE/NV Project Manager. The NDEP maintains the official Administrative Record for all activities conducted under the auspices of the FFACO. 


\subsection{References}

ASTM, see American Society for Testing and Materials.

American Society for Testing and Materials. 1996. Section 04.08 and 04.09, "Construction." In Annual Book of ASTM Standards. Philadelphia, PA.

BN, see Bechtel Nevada.

Bechtel Nevada. 1995. Nevada Test Site Performance Objective for Certification of Nonradioactive Hazardous Waste, Rev. 0. Las Vegas, NV.

CFR, see Code of Federal Regulations.

Code of Federal Regulations. 1996a. 40 CFR Part 261. "Identification and List of Hazardous Waste." Washington, DC: U.S. Government Printing Office.

Code of Federal Regulations. 1996b. 40 CFR Part 265, "Interim Status Standards for Owners and Operators of Hazardous Waste Treatment, Storage, and Disposal Facilities." Washington, DC: U.S. Government Printing Office.

Code of Federal Regulations. 1997a. 40 CFR Part 262, "Standards Applicable to Generators of Hazardous Waste." Washington, DC: U.S. Government Printing Office.

Code of Federal Regulations. 1997b. 49 CFR Part 172, "Hazardous Materials Table, Special Provisions, Hazardous Materials Communications, Emergency Response Information, and Training Requirements." Washington, DC: U.S. Government Printing Office.

DOE, see U.S. Department of Energy.

DOE/NV, see U.S. Department of Energy, Nevada Operations Office.

EPA, see U.S. Environmental Protection Agency.

FFACO, see Federal Facility Agreement and Consent Order.

Federal Facility Agreement and Consent Order. 1996. Agreed to by the State of Nevada, the U.S. Department of Energy, and the U.S. Department of Defense.

IT Corporation. 1997a. Initial Surface Geophysical Surveys for the Tonopah Test Range Environmental Restoration Sites, Volume 1 of 2, DOE/NV10972--93. Las Vegas, NV. 
IT Corporation. 1997b. Preliminary Assessment for CAU No. 407: Surface/Near-Surface Contamination Site CAS No. TA-23-001-TARC: Roller Coaster RADSAFE Area Tonopah Test Range, ITLV/13052--012. Las Vegas, NV.

LAS Laboratories, Inc. 1993. "Sample Preparation, Nuclide Separation and Analysis," Standard Operating Procedure LAL-91-SOP-0108. Las Vegas, NV.

McArthur, R.D., and F.L. Miller, Jr. 1989. Offsite Radiation Exposure Review Project (ORERP), Phase II Soils Programs, DOE/NV/10384-23. Las Vegas, NV: Desert Research Institute.

NAC, see Nevada Administrative Code.

National Academy of Science. 1963. Nuclear Science Series.

NDEP, see Nevada Division of Environmental Protection.

Nevada Administrative Code. 1990. NAC444.940 - NAC444.9555, "Solid Waste Disposal." Carson City, NV: Nevada Division of Environmental Protection.

Nevada Administrative Code. 1996a. NAC445A.345 - NAC445A.22755, "Corrective Action Regulations." Carson City, NV: Nevada Division of Environmental Protection.

Nevada Administrative Code. 1996b. NRS459.9973, 459.9975, and 459.9977, "Nevada Revised Statutes." Carson City, NV: Nevada Division of Environmental Protection.

Nevada Division of Environmental Protection. 1995. "Mutual Consent Agreement Between the State of Nevada and the Department of Energy for the Storage of Low-Level Land Disposal Restricted Mixed Waste." Transmittal from P. Liebendorfer (NDEP) to D. Elle (DOE/NV), 7 June. Carson City, NV.

Rarrick, Harold. Sandia National Laboratories (Retired). 1993. Interview with M. Theodorakos regarding Operation Roller Coaster, pages 13-16, 22 September. Las Vegas, NV.

Reynolds Electrical \& Engineering Co., Inc. 1963. Project Manager's Report, Project Roller Coaster. Prepared for U.S. Atomic Energy Commission, Nevada Operations Office. Las Vegas, NV.

Reynolds Electrical \& Engineering Co., Inc. 1966. Radiological Conditions at Project Roller Coaster. Prepared for U.S. Department of Energy, Nevada Operations Office. Las Vegas, NV.

Rodriguez, Cheryl. IT Corporation. 1997. E-mail to M. Hagenow and M. England regarding GPS Coordinates for the IT Monuments at TTR, 24 September. Las Vegas, NV. 
Science Applications International Corporation, R.E. Wright Environmental, Inc. 1988. First Quarter 1998 Surface Geophysical Survey Report Roller Coaster Radiation Safe Area Corrective Action Site TA-23-001-TARC at the Tonopah Test Range, Nevada, R.E. Wright Project 01-1408-08-3543-000. Middletown, PA.

Sygitowicz, Lee. Bechtel Nevada. 1997. Interviews with M. Hagenow (Science Applications International Corporation) regarding Operation Roller Coaster, 24, 25 September.

Las Vegas, NV.

USACE, see U.S. Army Corps of Engineers.

United States Army Corps of Engineers. 1970. "Laboratory Soils Testing." In Engineering Manual 1110-2-1906, Appendix II. Washington, DC.

U.S. Department of Energy. 1992. Environmental Measurements Laboratory Procedures Manual. HASL-300, 27th Edition, Volume 1. New York. NY.

U.S. Department of Energy. 1993. Radiation Protection of the Public and the Environment, DOE Order 5400.5. Washington, DC.

U.S. Department of Energy, Nevada Operations Office. 1994a. ERD-05-201, "Chain of Custody," Rev. 0. Las Vegas, NV.

U.S. Department of Energy, Nevada Operations Office. 1994b. Project Management Plan, Rev. 0. Las Vegas, NV.

U.S. Department of Energy, Nevada Operations Office. 1994c. ERD-05-701, "Sampling Equipment Decontamination," Rev. 0. Las Vegas, NV.

U.S. Department of Energy, Nevada Operations Office. 1994d. Instrument Calibration for Portable Survey Instruments, 6-10 CFR 835/E1-Rev. 1.

U.S. Department of Energy, Nevada Operations Office. 1996a. Corrective Action Unit Work Plan, Tonopah Test Range, Nevada, Rev. 0. Las Vegas, NV: IT Corporation.

U.S. Department of Energy, Nevada Operations Office. 1996b. Environmental Restoration Project Health and Safety Plan, Rev. 2. Las Vegas, NV.

U.S. Department of Energy, Nevada Operations Office. 1996c. NV/YMP Radiological Control Manual, Rev. 2, DOE/NV/11718-079, UC-702. Las Vegas, NV.

U.S. Department of Energy, Nevada Operations Office. 1996d. Industrial Sites Quality Assurance Project Plan. Nevada Test Site, Nevada, Rev. 1, DOE/NV--372. Las Vegas, NV. 
U.S. Department of Energy, Nevada Operations Office. 1996e. Streamlined Approach for Environmental Restoration Plan, CAU No. 400: Bomblet Pit and Five Points Landfill, Tonopah Test Range, DOE/NV--24. Las Vegas, NV.

U.S. Department of Energy, Nevada Operations Office. 1997. Nevada Test Site Waste Acceptance Criteria, Rev. 1. Las Vegas, NV.

U.S. Environmental Protection Agency. 1980. Prescribed Procedures for Measurement of Radioactivity in Drinking Water, EPA-600/4-80-032. Cincinnati, OH.

U.S. Environmental Protection Agency. 1994. Guidance for the Data Quality Objectives Process, EPA QA/G-4. Washington, DC.

U.S. Environmental Protection Agency. 1996a. Memo from Smucker, S.J. regarding Region 9 Preliminary Remediation Goals (PRGs), 01 August. San Francisco, CA: U.S. Environmental Protection Agency.

U.S. Environmental Protection Agency. 1996b. Test Methods for Evaluating Solid Waste, Physical/Chemical Methods, SW-846, 3rd Edition, CDROM, PB89-148076. Washington, DC. 
Appendix A

Data Quality Objectives 


\section{Data Quality Objectives}

The Scoping Team met January 7, 1998, to develop the DQOs for the corrective action investigation of the Roller Coaster RADSAFE Area, CAU 407. The DQO steps are listed systematically and build on the data acquired during background research. Copies of the background data are in project files.

\section{Identify the members of the Scoping Team:}

1.

Scoping Team

DOE/NV

Kevin Cabble

Janet Appenzeller-Wing

IT Corporation

Kenneth Beach

Mark DiStefano

Mary Todd (SAIC)

Syl Hersh

Jeanne Wightman (Mactec)

Bob McCall (SAIC)

Cindy Dutro

Steve Adams

Matt Hagenow (SAIC)

Barbara Deshler

2.

Core Decision Team

Kevin Cabble

Kenneth Beach

Dave Madsen

3. $\quad$ Primary Decision Makers

Janet Appenzeller-Wing

Kevin Cabble
NDEP

Karen Beckley

Bechtel

Dave Madsen

Shannon Parsons 


\section{A.1.0 Problem Statement}

\section{A.1.1 State the Problem}

Radioactive wastes and possibly hazardous wastes were disposed of at the Roller Coaster RADSAFE Area. Existing information is insufficient to evaluate and select a preferred corrective action.

\section{A.1.1.1 Problem to be resolved}

Verify the decon facility locations (vehicle and personnel decon areas, decon sumps, and the waste disposal pit), and determine whether COPCs are present in quantities exceeding regulatory levels. If contamination is detected, determine the extent in the release area and whether it presents a hazard to potential receptors.

\section{A.1.1.2 Describe the site history and known or suspected sources of contamination}

The Roller Coaster RADSAFE Area was used to decontaminate vehicles, equipment, and personnel from the Clean Slate tests. Based upon available information, the assumed area of concern at this site includes the former hotline area (personnel decon area), the vehicle decon area, two decon sumps, and the waste disposal pit. All but the former hotline area are assumed to be encompassed by a fenced area 21 meters $\times 76$ meters ( 70 feet $\times 250$ feet) that is posted as a radiological contamination area. The specific locations of the vehicle decon area, two decon sumps, and the waste disposal pit inside the fenced area are uncertain. Figure 2-1 includes a map of the area showing the location of the hotline and the assumed locations of the vehicle decon area, two decon sumps, and the waste disposal pit.

The former hotline area consisted of a trench, 0.6-0.9 meters (2-3 feet) deep, filled with gravel which served as a french drain for water used during the doffing of anticontamination clothing and personal protective equipment worn by personnel involved in the Clean Slate tests. Interviews indicate that the gravel was excavated and placed in the disposal pit. Geophysical surveys were conducted outside and just southwest of the fenced area in 1993. Ground-penetrating radar surveys were conducted over the depressed area (assumed to be the hotline) near the southwest corner of the fenced area. Results of 
these surveys indicate that there were no metallic debris found in the survey area. So far, geophysical surveys have not been conducted inside the fenced area due to site access restrictions.

The vehicle decon area (east of the hotline area) consisted of a pit, 1.2-1.8 meters (4-6 feet) deep, filled with gravel which served as a french drain for vehicle decon water. The water used came from a tank mounted on a vehicle equipped with a pressure washer. The water then drained from the vehicle decon area into the decon sumps (one primary, one secondary) to the east. The contaminated waste disposal pit lies to the east of the decon sumps and was covered with several feet of clean soil upon completion of decon activities.

The potential types of hazardous waste disposed at the site are not documented; however, interviews indicate that $\mathrm{MEK}$ and alcohol contaminated swabs from deconning of facemasks were disposed of in the waste disposal pit. Additionally, lead-acid batteries were decontaminated at the vehicle decon area, and the potential exists for some of these batteries to have been disposed of here.

Contaminants of potential concern and their locations include plutonium, depleted uranium, MEK, alcohol, lead, and sulfuric acid at the disposal pit, and SVOCs and petroleum hydrocarbons at the vehicle and equipment decon area and decon sumps. 


\section{A.2.0 Develop/Refine the Conceptual Model}

\section{A.2.1 Primary Model}

The primary model describes the most probable scenario for current conditions at the Roller Coaster RADSAFE Area. Proposed characterization methods are based upon the following assumptions:

- COPCs primarily in liquid form were released into the soil at the hotline, vehicle decon area, and the two decon sumps.

- Groundwater contamination is unlikely because environmental conditions at the site, such as an arid climate and low permeabilities, are not conducive to downward migration.

- COPCs is limited vertically to less than 9-m (30-ft) and horizontally to 3-m (10-ft) from the bottom and sides of the two decon sumps and the vehicle decon area.

- COPCs in the form of solids are in the waste disposal pit.

- Semivolatile organic compounds and hydrocarbons originating from vehicle decon activities are at low concentrations.

\section{A.2.2 Alternate Model}

Assumed conditions under the alternate model are considered less likely than assumed conditions under the primary model. Under the following conditions, the alternate model accounts for COPC migration beyond the immediate vicinity:

- Liquids contaminated with COPCs could have infiltrated more than 9-m (30-ft) vertically or more than $3-\mathrm{m}(10-\mathrm{ft})$ horizontally from either of the two decon sumps or the vehicle decon area.

- If vertical migration of COPCs is greater than approximately $120-\mathrm{m}$ (400-ft), groundwater could potentially be contaminated. This scenario is not considered likely. 


\section{A.3.0 Identify the Decision}

Select the appropriate decision for the current phase of the site assessment process:

- Determine the types and concentrations of contaminants present at the site.

- Determine if contaminant concentrations exceed regulatory standards and/or standards for the protection of human health and the environment.

- Determine the extent of contamination with enough certainty to develop and evaluate a range of potential corrective actions for the site, including closure in place and clean closure. 


\section{A.4.0 Identify the Inputs to the Decision}

\section{A.4.1 Identify the information inputs needed to resolve the decision and prepare a list of all the data needed to solve the decision:}

- Contaminant identification - Analysis of soils for COPCs identified in Section A.4.2

- Action level exceedance - Analytical results will be compared to preliminary action levels.

- Contaminant migration

- Boundaries of contaminant migration from indicator parameters and/or analyses of soils for the parameters listed in Section A.4.2

- Soil physical characteristics (hydrological and geotechnical) (if COPCs exceed 0.6-m [2-ft] in depth)

- Risk evaluation - Determination of soil concentrations to support development of risk-based action levels and to evaluate risk to workers and risk to environment beyond what currently exists

- Waste management - Analytical results sufficient for waste determination and disposal

\section{A.4.2 List types of potential contaminants and affected media}

The following is the list of COPCs based on process knowledge:

- Plutonium - surface and subsurface soils

- Depleted uranium - surface and subsurface soils

- VOCs - surface and subsurface soils

- SVOC - surface and subsurface soils

- Metals - surface and subsurfaces soils

- TPH-grease and oil fractions - surface and subsurface soils.

Radionuclides other than plutonium and depleted uranium, pesticides, and polychlorinated biphenyls are COPCs based on related activity sites (pesticides were identified at Roller Coaster Sewage Lagoon, CAU 404) or as a precautionary measure.

- Pesticides and PCBs

- Radionuclides other than plutonium 


\section{A.4.3 Identify potential sampling approaches and appropriate analytical methods}

Conduct biased sampling directed by process knowledge. geophysical studies, and the results of observations and field screening during the field investigation to confirm or refute the conceptual model for the site, to assess the migration of the COPCs, and to determine if COPCs are present in concentrations exceeding the action levels for the site. In regions exceeding preliminary action levels, horizontal step-outs or deeper investigations would be used to assess the potential migration of subsurface contaminants.

Representative sampling will consist of analysis for the contaminants listed in Step A.4.2, with a possible reduction in the case of non-detects or results below preliminary action levels, as appropriate.

Analytical parameters selected are based on process knowledge and requirements specified by the NDEP. The following list (see Table 3-1) specifies analyses that will be conducted to assess the most likely contaminants:

- Plutonium - isotopic plutonium

- Depleted uranium - isotopic uranium

- Total VOCs - 8260

- SVOCs -8270

- Metals - 6010/7470

- TPH - 8015 modified

In addition, to ensure that any possible contaminants are found (if present), selected samples will also be analyzed using the following methods:

- Radionuclides - HASL-300

- Pesticides/PCBs -8080

The following geotechnical analyses are also included:

- Initial moisture content

- Dry bulk density

- Calculated porosity

- Saturated/unsaturated hydraulic conductivity

- Particle size distribution and hydrometer

- Moisture retention characteristics 


\section{A.5.0 Define the Boundaries of the Study}

\section{A.5.1 Define the geographic areas of the field investigation}

The study area at the RCRSA includes the vehicle decon area, the two decon sumps, the hotline area, and the waste disposal pit. To facilitate investigation activities, a waste management area will be defined. All contaminated equipment traffic will be within the defined study area boundaries, with appropriate decontamination conducted prior to exiting the boundaries. All investigation-derived waste will be accumulated within the boundaries of the study area.

\section{A.5.2 Define the temporal boundaries of the decision}

The time frame to which the study data apply depend on the following:

- Laboratory hold time for analytical samples

- IDW sample holding times

- The deadline for the CADD is March 31, 1999.

- The data collection time frame begins after approval of the CAIP and allows for finalizing data collection and evaluation to support the CADD deadline.

- Migration (if occurring) is assumed to be imperceptibly slow with no waste input since 1963 and minimal surface water infiltration.

\section{A.5.2.1 Determine when to collect data}

Field activities are scheduled to take place June and July of 1998, pending approval of the CAIP.

\section{A.5.3 Identify any practical constraints on data collection}

The following items may include data collection:

- Meteorological - Data will not be collected during inclement weather that may affect health and safety or data quality.

- Health and safety - Data will be collected under an approved site-specific health and safety plan.

- Heavy equipment and resource availability - Data collection will require coordination with other site activities to ensure availability of equipment and resources. 
- Approval of the CAIP - The approval of the CAIP serves as the starting point for the data collection; activities, such as preparing field instructions and site-specific health and safety plans, can run concurrently with the CAIP approval process.

- Site access - Activities by other site users may affect access to the site. 


\section{A.6.0 Develop a Decision Rule - Define a Logical Basis for Choosing Among Alternative Actions}

\section{A.6.1 Specify the action level or preliminary action level for the decision}

Preliminary action levels for the site will be determined based on Nevada Administrative Code (NAC) 445A requirements (NAC, 1996a) and 40 CFR 261.24 (CFR, 1996a), the toxicity characteristic leaching procedure (TCLP). The NAC establishes multiple criteria for determining action levels. If more than one action level for soil has been established using the above-referenced criteria, the most restrictive action level is to be used. Instead of directly analyzing samples by TCLP, values will be calculated by dividing the total analytical result by twenty. This is done for 100 percent solid media (such as soil) by dividing the total concentration by 20 . Additional information to support development of preliminary action levels is available in the Integrated Risk Information System, in the EPA Region IX Preliminary Remediation Goals (PRGs) for industrial sites, and risk-based levels modeled to site-specific conditions (EPA, 1996a). The following guidelines for establishing preliminary action levels for radionuclides were discussed in the DQO:

- DOE Order 5400.5 (DOE, 1993)

- NTSWAC (DOE, 1997)

- Performance Objective Criteria (POC) (BN, 1995)

Preliminary action levels for radionuclides are concentrations greater than twice the established background level. The DOE, NDEP, and the U.S. Air Force are currently negotiating a corrective action limit for radionuclides.

\section{A.6.2 Specify the variables acting on the corrective action decisions}

The preferred corrective action alternative will be based on an evaluation of the nature and extent of contamination. Because of the potential for generating a hazardous waste stream during any removal actions which would require treatment or disposal, the economic viability of the removal type alternative is dependent on the volume of contaminated material. If the data collection activities reveal a larger than expected contaminated volume, then a risk-based approach will be considered for the site to evaluate closure in place. This will require data collection to support development of risk-based action levels. 


\section{A.7.0 Sampling Design}

\section{A.7.1 Develop general sampling and analysis design}

The field investigation at CAU 407 will consist of biased sampling to decide if COPCs are present, their distribution, and if preliminary action levels are exceeded. The following areas and activities are proposed for the field investigation:

- Hotline - Conduct surface and near-surface biased sampling.

- Vehicle decon - Conduct surface and subsurface biased sampling.

- Decon sumps - Conduct surface and subsurface biased sampling at the western-most sump.

- Disposal pit - Conduct surface and subsurface biased sampling.

- Background - Conduct surface and subsurface sampling.

- Conduct field screening for VOCs and radiological constituents at all sample locations.

- Conduct geophysical surveys inside the fenced area to identify buried metallic debris.

- Conduct GPR surveys to identify location of vehicle decon area, sumps and waste disposal pit.

\section{A.7.2 Select the most resource-effective sampling design that satisfies all of the DQOs}

The subsurface soil is proposed to be investigated using a sonic drill rig equipped with a core barrel sampler. The primary purpose for using the sonic drilling method (versus hollow-stem auger) is to identify the contact between the fill material and native soil and to reduce the amount of IDW. This will also allow drilling to be performed directly through the waste disposal pit and to provide definitive data about actual waste types and subsurface conditions.

Biased sampling will entail collecting environmental and field-screening samples from the surface and subsurface to confirm or refute the conceptual model for the site, to assess the migration of contaminants, and to determine if contaminants are present in concentrations exceeding preliminary action levels for the site. The highest potential contamination area based on field screening will be 
targeted for an upper bounding sample. Other sample locations will be targeted to define the extent of the contaminated area above action levels. Regions exceeding preliminary remediation goals would necessitate horizontal step-out sample collection locations or deeper borings to investigate potential contaminant migration.

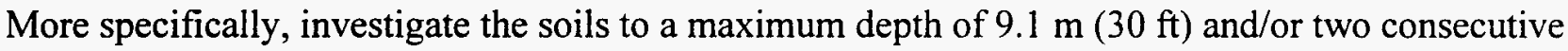
intervals below appropriate screening levels as determined by field screening and/or other analytical methods. The field screening methods will consist of headspace testing for VOCs and radiological screening for alpha and beta/gamma emitters. Representative sampling will consist of analysis for the parameters identified in Step A.4.3 for all samples, with a possible reduction to a limited analysis suite in the case of non-detects or results below preliminary action levels, as appropriate. After evaluation of acquired data (if necessary), advance step-out borings or deeper sampling as needed to bound the lateral and vertical extent of contamination.

Records will be kept of the soil description, field-screening measurements, and all other relevant data. All pertinent and required sampling information (i.e., date, time, sample interval) will be documented in accordance with the Industrial Sites QAPP (DOE/NV, 1996d). Approved Chain of Custody procedures (DOE/NV, 1994a) will be followed to ensure the defensibility of the data.

\section{A.7.3 Document the operational details and theoretical assumptions of the selected design in the sampling and analysis plan}

Detailed documentation of sampling and analysis operations are contained in the Corrective Action Investigation Plan. 
Appendix B

Project Organization 


\section{B.1.0 Project Organization}

The DOE/NV Project Manager is Janet Appenzeller-Wing, telephone (702) 295-0461.

The names of the project Health and Safety Officer and the Quality Assurance Officer can be found in the appropriate DOE/NV plan. However, personnel are subject to change, and it is suggested that the Project Manager be contacted for further information. The Task Manager will be identified in the FFACO Biweekly Activity Report prior to the start of field activities. 
Appendix C

NDEP Document Review Sheets 


\section{NEVADA ENVIRONMENTAL RESTORATION PROJECT}

DOCUMENT REVIEW SHEET

\section{(Page 1 of 3 )}

\begin{tabular}{|c|c|c|c|c|c|}
\hline \multicolumn{4}{|c|}{ 1. Document Title/Number: Draft CAIP for the Roller Coaster RADSAFE Area CAU 407, TTR } & \multicolumn{2}{|l|}{ 2. Document Date: February 1998} \\
\hline \multicolumn{4}{|c|}{ 3. Revision Number: 0} & \multicolumn{2}{|c|}{ 4. Originator/Organization: IT Corporation } \\
\hline \multicolumn{4}{|c|}{ 5. Responsible DOE/NV ERP Subproject Mgr.: } & \multicolumn{2}{|l|}{ 6. Date Comments Due: } \\
\hline \multicolumn{6}{|c|}{ 7. Review Criteria: } \\
\hline \multicolumn{3}{|c|}{ 8. Reviewer/Organization/Phone No.: NDEP } & & \multicolumn{2}{|l|}{ 9. Reviewer's Signature: } \\
\hline $\begin{array}{l}10 . \\
\text { Comment } \\
\text { Number/ } \\
\text { Location }\end{array}$ & $\begin{array}{c}11 . \\
\text { Type* }\end{array}$ & 12. Comment & \multicolumn{2}{|c|}{ 13. Comment Response } & $\begin{array}{c}14 . \\
\text { Accept }\end{array}$ \\
\hline $\begin{array}{c}1 . \\
\text { Section } 2.5 \\
\text { page } 10\end{array}$ & & $\begin{array}{l}\text { DOE states that geophysical and radiation surveys have been } \\
\text { conducted and the results of these surveys will be incorporated } \\
\text { into the final revision of the CAIP. NDEP may have additional } \\
\text { concerns that may need to be addressed prior to approval of the } \\
\text { final CAIP based on this additional information. }\end{array}$ & \multicolumn{2}{|c|}{$\begin{array}{l}\text { Changes to the CAlP in regards to the } 1998 \text { geophysical survey results } \\
\text { were added to Section } 2.5 \text { beginning with the third paragraph. Two new } \\
\text { figures were also added (Figures } 2-3 \text { and } 2-4 \text { ). }\end{array}$} & \\
\hline $\begin{array}{l}2 . \\
\text { Section } 3.2, \\
\text { page } 12\end{array}$ & & $\begin{array}{l}\text { Based on the operational history presented in Section } 2.2 \text { on } \\
\text { page 7, DOE needs to consider DU as a "contaminant of } \\
\text { potential concern." }\end{array}$ & \multicolumn{2}{|c|}{$\begin{array}{l}\text { DU is now listed as a contaminant of potential concern (COPC) in the } \\
\text { Roller Coaster RADSAFE Area CAIP. } \\
\text { There is a possibility that metal plates and concrete debris from the } \\
\text { Roller Coaster Sites were buried in a waste pit in the RADSAFE Area. } \\
\text { Though it is unlikely that DU will be found in the waste pit, soil samples } \\
\text { designated to be sent to the laboratory will be analyzed for isotopic } \\
\text { uranium. This type of analysis is preferred to total uranium analysis } \\
\text { using Kinetic Phosphorescence Analysis because isotopic uranium is } \\
\text { more accurate, more precise, and provides concentration data on } \\
\text { uranium isotopes that can be used to determine whether or not the } \\
\text { source of the uranium is natural uranium or depleted uranium. }\end{array}$} & \\
\hline
\end{tabular}




\section{NEVADA ENVIRONMENTAL RESTORATION PROJECT} DOCUMENT REVIEW SHEET

(Page 2 of 3 )

\begin{tabular}{|c|c|c|c|c|}
\hline $\begin{array}{l}10 . \\
\text { Comment } \\
\text { Numberl } \\
\text { Location }\end{array}$ & $\begin{array}{l}11 . \\
\text { Type* }\end{array}$ & 12. Comment & 13. Comment Response & $\begin{array}{c}14 . \\
\text { Accept }\end{array}$ \\
\hline $\begin{array}{l}3 . \\
\text { Section } 3.3 \\
\text { page } 13\end{array}$ & & It is unclear why a "daily" background needs to be established. & $\begin{array}{l}\text { Radiological monitoring instruments, as with all measuring devices, will } \\
\text { always display random and systematic variations in their measurement } \\
\text { output, even when presented with the same radiation flux. In addition, } \\
\text { radioactive decay is a random process. In order to ensure the } \\
\text { instruments are responding correctly and have not drifted to an } \\
\text { unacceptable degree, daily background measurements are taken. This } \\
\text { is in keeping with good practices for performing radiological monitoring } \\
\text { and is recommended by the Department of Energy in } 10 \text { CFR } 835 \text {, } \\
\text { Implementation Guide G-10, "Instrument Calibration for Portable Survey } \\
\text { Instruments" (DOE, 1994d). }\end{array}$ & \\
\hline 4. & & $\begin{array}{l}\text { Throughout the document, reference is made to field screening } \\
\text { for radiological constituents. Clarification of how this screening } \\
\text { will be conducted needs to be provided. }\end{array}$ & $\begin{array}{l}\text { The CAIP has been modified in Section } 4.1 .2 \text { to include a brief } \\
\text { description of why field screening is being performed and how the } \\
\text { FIDLER and microroentgen survey instruments may be used in } \\
\text { performing the field screening. }\end{array}$ & \\
\hline $\begin{array}{l}5 . \\
\text { Section 4.1.3, } \\
\text { Page } 19\end{array}$ & & $\begin{array}{l}\text { It is unclear what is being proposed in the first two sentences of } \\
\text { this paragraph. An "increased sampling interval" implies fewer } \\
\text { samples where an increased sample "frequency" would imply } \\
\text { more samples. The sampling starts at " } 5 \mathrm{ft} \text { intervals" and } \\
\text { changes to "up to } 1 \mathrm{ft} \text { intervals." What is the intent; to increase } \\
\text { the sampling frequency to every } 1 \text { foot interval for } 5 \text { feet? }\end{array}$ & $\begin{array}{l}\text { The intent is to increase the sampling frequency to up to every } 1 \text { foot } \\
\text { beginning at the interface of the native soil and fill material and } \\
\text { continuing downward for } 5 \mathrm{ft} \text {. "Interval" was replaced by "frequency" in } \\
\text { the sentence. This will provide precise information on vertical } \\
\text { distribution of rad COPCs to support evaluation of corrective action in the } \\
\text { CADD. }\end{array}$ & \\
\hline $\begin{array}{l}6 . \\
\text { Section } 5.3, \\
\text { Page } 23\end{array}$ & & $\begin{array}{l}\text { DOE references the DOE/NV Radiological Control Manual } \\
\text { (DOE/NV 1996). The latest copy NDEP is dated } 1992 \text {. Please } \\
\text { provide one copy of the } 1996 \text { version to the NDEP/LV office and } \\
\text { one to the NDEP/CC office for review. }\end{array}$ & $\begin{array}{l}\text { One copy of this manual was sent "Federal Express" to Dick Serdoz at } \\
\text { NDEP/LV and Karen Beckley at NDEP/CC on 04/07/98. }\end{array}$ & \\
\hline $\begin{array}{l}7 . \\
\text { Section } 5.3, \\
\text { Page } 23\end{array}$ & & $\begin{array}{l}\text { Where will the equipment swipes be counted? If in the field, } \\
\text { what is the sensitivity of the instrument to be used? }\end{array}$ & $\begin{array}{l}\text { The equipment swipes will be counted in the field using the protean low } \\
\text { background counting system Model IPC- } 9025 \text { and standard operating } \\
\text { procedures. This system has demonstrated the necessary sensitivity } \\
\text { and minimum deteclable concentration to ensure compliance with the } \\
\text { requirements listed in Table } 2-2 \text { of the NVIYMP Radiological Control } \\
\text { Manual for free unrestricted release of equipment from radiological } \\
\text { areas. }\end{array}$ & \\
\hline
\end{tabular}


NEVADA ENVIRONMENTAL RESTORATION PROJECT

\section{DOCUMENT REVIEW SHEET}

(Page 3 of 3 )

\begin{tabular}{|c|c|c|c|c|}
\hline $\begin{array}{l}10 . \\
\text { Comment } \\
\text { Numberl } \\
\text { Location }\end{array}$ & $\begin{array}{c}11 . \\
\text { Type* }\end{array}$ & 12. Comment & 13. Comment Response & $\begin{array}{c}14 . \\
\text { Accept }\end{array}$ \\
\hline $\begin{array}{l}8 . \\
\text { Section } 6.1 \\
\text { Page } 28\end{array}$ & & $\begin{array}{l}\text { Day } 110 \text { states that the samples will be shipped to the laboratory } \\
\text { for analysis. This statement potentially conflicts with the holding } \\
\text { times of some of the contaminants of potential concern. }\end{array}$ & $\begin{array}{l}\text { This part of the sentence was deleted. A sentence was added to the } \\
\text { "Day } 60 \text { " stating that samples will be shipped to meet laboratory holding } \\
\text { times. }\end{array}$ & \\
\hline $\begin{array}{l}9 . \\
\text { Page } 31\end{array}$ & & $\begin{array}{l}\text { DOE utilizes a reference of "NVYMMP Radiological Control } \\
\text { Marlual," Rev. } 2 \text {. The latest copy NDEP has is Rev. } 1 \text {. Please } \\
\text { provide one copy of Rev. } 2 \text { to the NDEP/LV office and one to the } \\
\text { NDEP/CC office for review. }\end{array}$ & $\begin{array}{l}\text { One copy of this manual was sent "Federal Express" to Dick Serdoz at } \\
\text { NDEP/LV and Karen Beckley at NDEP/CC on 04/07/98. }\end{array}$ & \\
\hline $\begin{array}{l}10 . \\
\text { Appendix A, } \\
\text { Section A.6.1, } \\
\text { Page A-10 }\end{array}$ & & $\begin{array}{l}\text { The second sentence provides an obscure discussion of the } \\
\text { TCLP evaluation. A slight elucidation of the issue should be } \\
\text { provided. }\end{array}$ & The TCLP discussion was expanded in Section A.6.1 of the CAIP. & \\
\hline
\end{tabular}

a Comment Types: $M=$ Mandatory, $S=$ Suggested.

Return Document Review Sheets to DOE/NV Environmental Restoration Division, Attn: QAC, M/S 505 


\section{Distribution}

* Provide copy on initial distribution of Rev. 0 ; remainder of list gets Rev. 0 if approved without changes, and entire list receives distribution of Rev. 1, if issued.

Paul J. Liebendorfer

State of Nevada

Bureau of Federal Facilities

Division of Environmental Protection

333 W. Nye Lane, Room 138

Carson City, NV 89706-0851

Donald A. Garrepy

State of Nevada

Bureau of Federal Facilities

Division of Environmental Protection

555 E. Washington, Suite 4300

Las Vegas, NV 89101

Sabrina Bonnell

Environmental Restoration Division

DOE/Nevada Operations Office

P.O. Box 98518, M/S 505

Las Vegas, NV 89193-8518

Janet Appenzeller-Wing

Environmental Restoration Division

DOE/Nevada Operations Office

P.O. Box 98518, M/S 505

Las Vegas, NV 89193-8518

Kevin Cabble

Environmentai Restoration Division

DOE/Nevada Operations Office

P.O. Box 98518, M/S 505

Las Vegas, NV 89193-8518

Technical Information Resource Center DOE/Nevada Operations Office

P.O. Box 98518 , M/S 505

Las Vegas, NV 89193-8518
2 (Controlled) $^{*}$

1 (Controlled)*

1 (Controlled)*

1 (Uncontrolled)*

1 (Uncontrolled)*

2 (Uncontrolled) 
P.O. Box 62

Oak Ridge, TN 37831

DOE Public Reading Room

P.O. Box 98521 , M/S NLV040

Las Vegas, NV 89193-8521

Dave Madsen

Bechtel Nevada

P.O. Box 98521, M/S NTS306

Las Vegas, NV 89193-8521

Shannon Parsons

Bechtel Nevada

P.O. Box 98521, M/S NTS306

Las Vegas, NV 89193-8521

Dustin Wilson

SAIC

P.O. Box 93838

Las Vegas, NV 89193

Cheryl Rodriquez

HSI GeoTrans

P.O. Box 93838

Las Vegas, NV 89193

IT Corporation Central Files

P.O. Box 93838

Las Vegas, NV 89193

Rosa Silver

IT Corporation

P.O. Box 93838

Las Vegas, NV 89193

Mark DiStefano

IT Corporation

P.O. Box 93838

Las Vegas, NV 89193
1 (Controlled)

1 (Uncontrolled)

1 (Uncontrolled)*

1 (Uncontrolled)*

1 (Uncontrolled)*

1 (Uncontrolled)*

1 (Uncontrolled)*

2 (Controlled)

1 (Uncontrolled)* 
Bob McCall

\section{SAIC}

P.O. Box 93838

Las Vegas, NV 89193

Mary Todd

SAIC

P.O. Box 93838

Las Vegas, NV 89193
1 (Uncontrolled)

1 (Uncontrolled) 


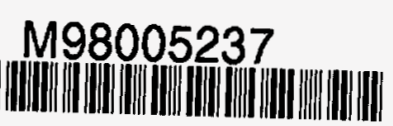

Report Number (14) DOE/NV - -503

Publ. Date (11)

Sponsor Code (18)

UC Category (19)

$\frac{199804}{D O E / D P, X F}$
$U C-700, D O E / E R$

